University of Nebraska - Lincoln

DigitalCommons@University of Nebraska - Lincoln

\title{
Geochemical Processes Controlling Migration of Tank Wastes in Hanford's Vadose Zone
}

John M. Zachara

Pacific Northwest National Laboratory, john.zachara@pnl.gov

Jeff Serne

Pacific Northwest National Laboratory

Mark Freshley

Pacific Northwest National Laboratory

Fred Mann

CH2M-HILL Hanford Group, Inc.

Frank Anderson

CH2M-HILL Hanford Group, Inc.

See next page for additional authors

Follow this and additional works at: https://digitalcommons.unl.edu/usdoepub

Part of the Bioresource and Agricultural Engineering Commons

Zachara, John M.; Serne, Jeff; Freshley, Mark; Mann, Fred; Anderson, Frank; Wood, Marcus; Jones, Tom; and Myers, Dave, "Geochemical Processes Controlling Migration of Tank Wastes in Hanford's Vadose Zone" (2007). US Department of Energy Publications. 301.

https://digitalcommons.unl.edu/usdoepub/301

This Article is brought to you for free and open access by the U.S. Department of Energy at DigitalCommons@University of Nebraska - Lincoln. It has been accepted for inclusion in US Department of Energy Publications by an authorized administrator of DigitalCommons@University of Nebraska - Lincoln. 


\section{Authors}

John M. Zachara, Jeff Serne, Mark Freshley, Fred Mann, Frank Anderson, Marcus Wood, Tom Jones, and Dave Myers 


\title{
Geochemical Processes Controlling Migration of Tank Wastes in Hanford's Vadose Zone
}

\author{
John M. Zachara, ${ }^{*}$ Jeff Serne, Mark Freshley, Fred Mann, Frank Anderson, Marcus Wood, \\ Tom Jones, and Dave Myers
}

\begin{abstract}
Nuclear wastes from Hanford's processing for separation of plutonium are stored in massive, buried, single-shell tanks in 18 tank farms. These so-called tank wastes were initially thermally hot because of radioactive decay, and many exhibited extreme chemical character in terms of $\mathrm{pH}$, salinity, and radionuclide concentration. At present, 67 of the 149 single shell tanks are suspected to have released over 1.9 million L of tank waste to the vadose zone, with most leak events occurring between 1950 and 1975. Boreholes have been placed through the largest vadose zone plumes to define the extent of contaminant migration and to develop conceptual models of processes governing the transformation, retardation, and overall transport of tank waste residuals. Laboratory studies with sediments so collected have shown that ion exchange, precipitation and dissolution, and surface complexation reactions have occurred between the tank wastes and subsurface sediments, moderating their chemical character and retarding the migration of select contaminants. Processes suspected to facilitate the far-field migration of immobile radionuclides including stable aqueous complex formation and mobile colloids were found to be potentially operative but unlikely to occur in the field, with the exception of cyanide-facilitated migration of ${ }^{60} \mathrm{Co}$. Certain fission product oxyanions $(\mathrm{Mo}, \mathrm{Ru}, \mathrm{Se}, \mathrm{Tc})$ and nitrates are the most mobile of tank waste constituents because their adsorption is suppressed by large concentrations of waste anions, the vadose zone clay fraction is negative in surface charge, and, unlike Cr, their reduced forms are unstable in oxidizing environments. Reaction/process-based transport modeling is beginning to be used for predictions of future contaminant mobility and plume evolution.
\end{abstract}

ABBREVIATIONS: AmOx, ammonium oxalate; CEC, cation exchange capacity; DBP, dibutyl phosphate; DCB, dithionite-citrate-bicarbonate; DST, double-shell tank; EDTA, ethylenediamine tetraacetic acid; PUREX, plutonium and uranium recovery by extraction; SST, single-shell tank.

$\mathrm{T}$ he Hanford Site in south-central Washington State produced plutonium for the USDOE weapons program from 1943 to 1989. Plutonium $(\mathrm{Pu})$ production involved the fission of uranium fuels using nine nuclear reactors along the Columbia River, followed by the extraction and concentration of trace product $\mathrm{Pu}$ through chemically intensive processing regimes performed in the central portion of the site. Three primary processing schemes were used during the lifetime of Hanford (bismuth phosphate [1944-1956], redox [1952-1967], and plutonium and uranium recovery by extraction [PUREX; 1956-1972, 1983-1989]), as improvements were sought to reduce waste volumes, allow $\mathrm{U}$ separation for reuse, and enhance Pu recovery efficiency.

Large volumes of radioactive waste were generated by processing, and the waste chemistry and composition varied markedly between the three processing schemes. The most concentrated and radioactive of these wastes were sent to 177 under-

J.M. Zachara, J. Serne, and M. Freshley, Pacific Northwest National Lab., P.O. Box 999, MS K8-96, Richland, WA 99354; F. Mann, F. Anderson, T. Jones, and D. Myers, CH2M-HILL Hanford Group, Inc., Richland, WA; M. Wood, Fluor Hanford, Richland, WA. Received 15 Dec. 2006. *Corresponding author (john.zachara@pnl.gov).

Vadose Zone J. 6:985-1003

doi:10.2136/vzj2006.0180

(C) Soil Science Society of America

677 S. Segoe Rd. Madison, WI 53711 USA.

All rights reserved. No part of this periodical may be reproduced or transmitted in any form or by any means, electronic or mechanical, including photocopying, recording, or any information storage and retrieval system, without permission in writing from the publisher. ground waste storage tanks. The first of these were single-shell tanks. The 149 large, single-shell, steel/concrete underground storage tanks ranged in volume from 209,000 L (55,000 gal) to $>3.8$ million L (1.0 million gal) (See Fig. 1, the S-SX tank farm under construction) with a total storage volume of 357
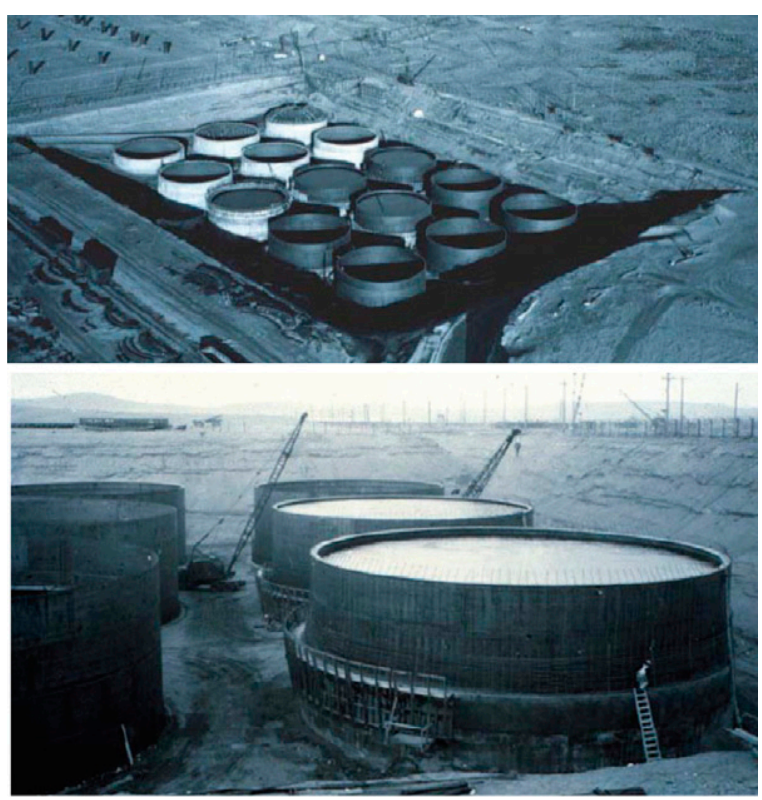

FIG. 1. The S-SX single-shell tank farm under construction in 1941. Note cranes for scales. The tank bottoms were $16.8 \mathrm{~m}$ below ground surface. (From Knepp, 2002a.) 

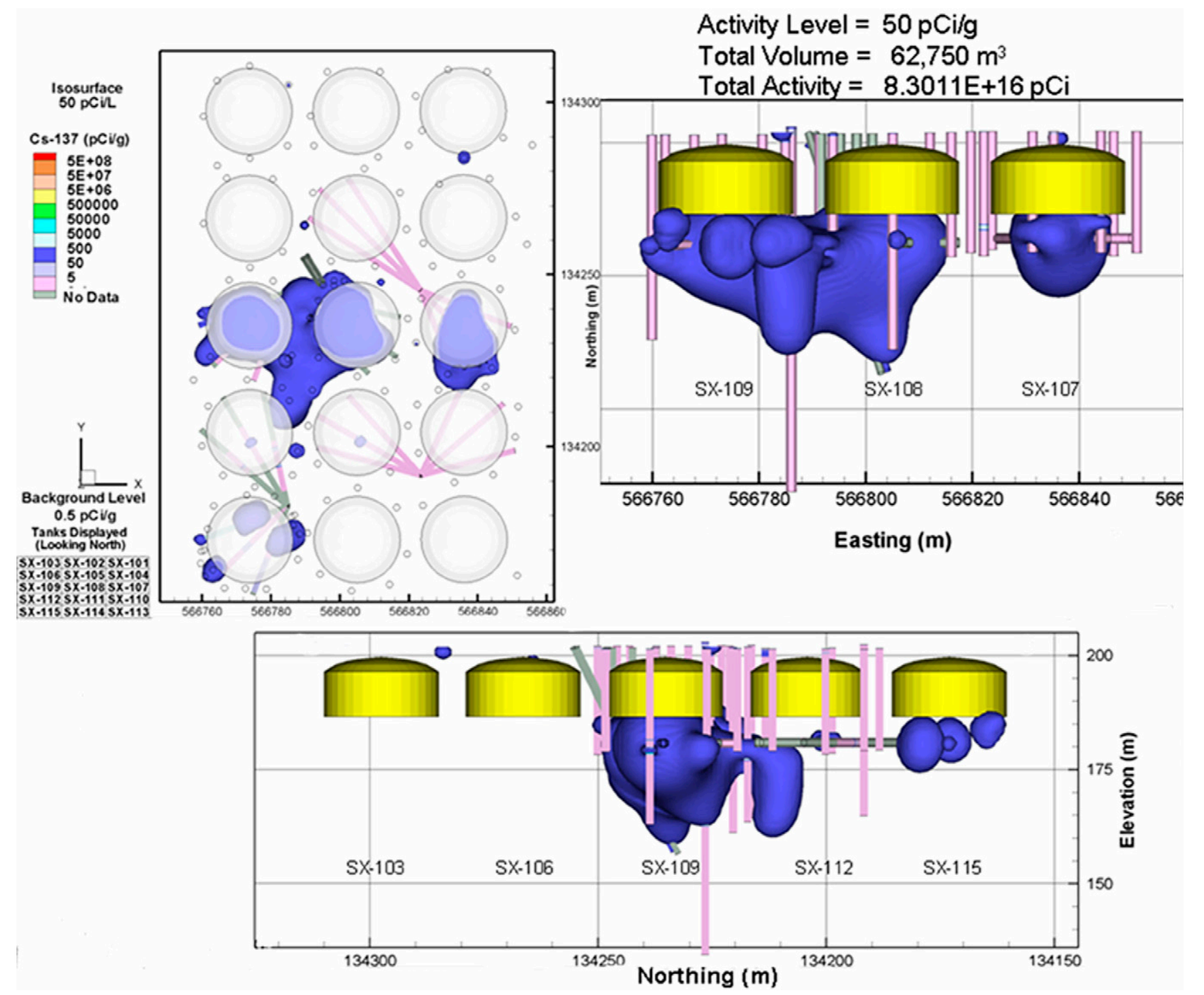

FIG. 2. Distribution of sorbed ${ }^{137} \mathrm{Cs}^{+}$beneath leaked tanks SX-108, SX-109, and others in S-SX tank farm. Data collected by downhole spectral gamma monitoring through an extensive dry borehole array. Three-dimensional data obtained by kriging. (From Knepp, 2002a.)

million L (94 million gal). The larger tanks were massive: 13.7 $\mathrm{m}(45 \mathrm{ft})$ in depth and $22.9 \mathrm{~m}(75 \mathrm{ft})$ in diameter (Gephart and Lundgren, 1996). These were situated below ground and were covered with approximately $3 \mathrm{~m}$ of soil and gravel. The tanks are located within 18 different groupings, termed tank farms, in the central portion of the Hanford Site, some 11 to $16 \mathrm{~km}$ from the Columbia River. The wastes were stored to allow the decay of highly radioactive, short-lived isotopes and to allow the secondary extraction of $U$ from bismuth phosphate wastes and other desired constituents. Tank storage was originally intended to be interim. It was the USDOE's intent to seek means for the permanent disposal of tank wastes within $20 \mathrm{yr}$ of generation, but this has not been accomplished even to this day.

Leaks from single-shell tanks were first suspected in 1956 and confirmed in 1959. Monitoring systems were installed in the tank farms to ensure the integrity of the storage tanks and their entrained waste, including fluid depth monitors in the tanks and numerous cased, dry boreholes in the vadose zone to monitor soluble, gamma-emitting radionuclides such as shortlived, anionic ${ }^{106} \mathrm{Ru}$, mobile ${ }^{60} \mathrm{Co}$, and waste-dominant ${ }^{137} \mathrm{Cs}$ (Fig. 2). These monitoring systems have indicated the loss of tank waste from the single-shell tanks, or their respective ancillary piping, into the vadose zone, which extends 50 to $70 \mathrm{~m}$ below ground surface. The leakage resulted from tank failure, tank overfilling, and breaches in transfer lines that brought the waste to and from the tanks. The total volume of tank waste loss has been difficult to determine but ranges between 1.9 million L (500,000 gal) and 3.8 million L (1 million gal), containing about 1,000,000 curies of radioactivity. Some of the waste materials lost exhibited extreme chemistry and high heat. This leakage has been augmented with natural recharge of meteoric water in the tank farms enhanced by gravel covers (Khaleel et al., 2007) and artificial recharge resulting from water line leakage and other infrastructure sources. Leaked tank wastes have been in contact with surrounding vadose zone sediments for decades and have undergone significant geochemical and radiological transformations. Mobile, anionic tank waste contaminants [e.g., ${ }^{9} \mathrm{Tc}(\mathrm{VII}) \mathrm{O}_{4}{ }^{-}, \mathrm{Cr}(\mathrm{VI}) \mathrm{O}_{4}{ }^{2-}, \mathrm{NO}_{3}{ }^{-}$] have been observed in groundwaters beneath some of the tank farms, leading to concern over the future mobility of the uncontained tank waste inventory in the vadose zone. 


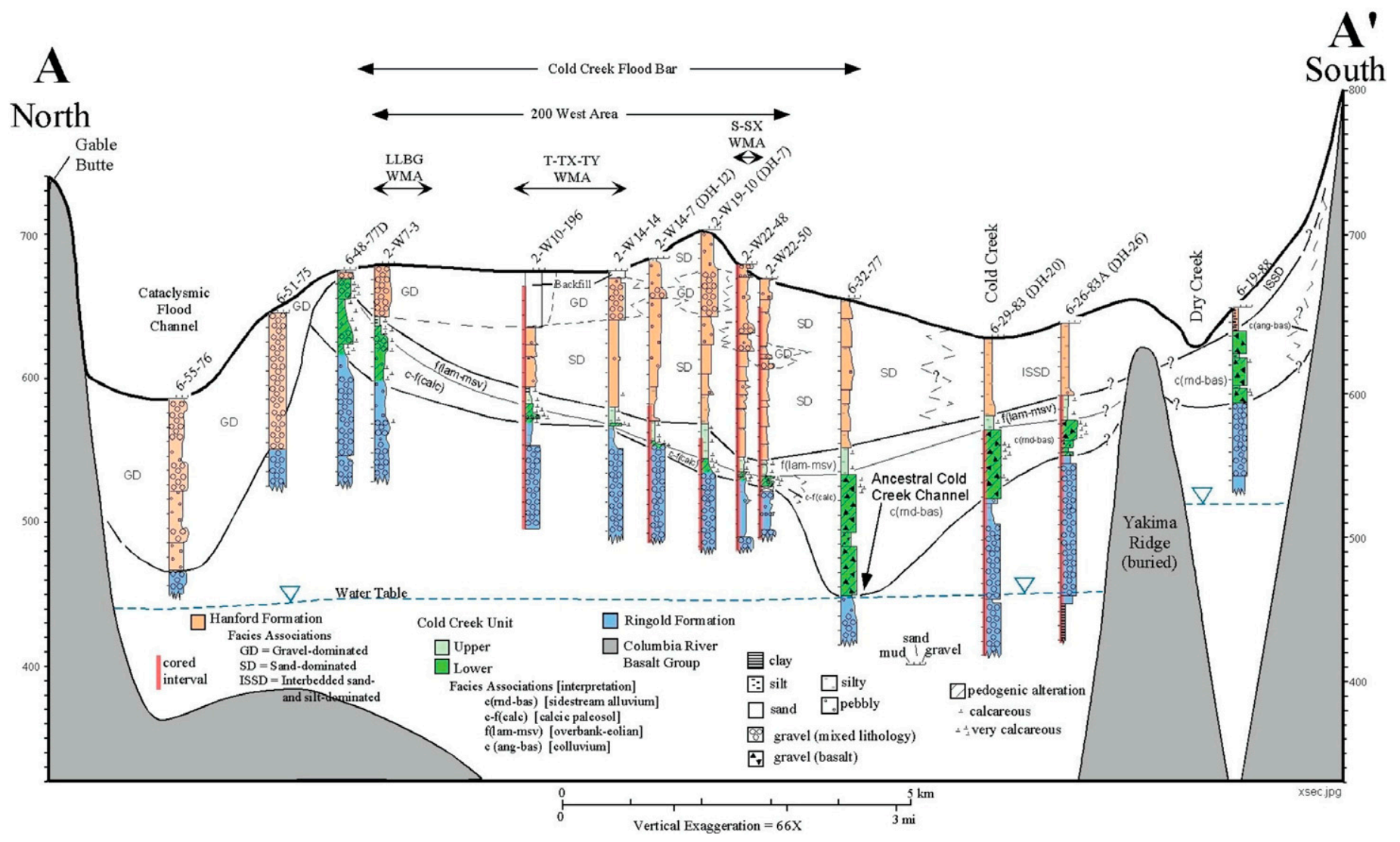

FIG. 3. North-south geological transect through Hanford's 200A plateau where waste processing facilities and tank farms exist. (From Serne et al., 2004a.)

Since 1998, the Hanford Site has been actively characterizing the in-ground distribution of contaminants within the largest tank waste releases and associated vadose zone contaminant plumes (e.g., SX-108; BX-102, T-106 [Knepp, 2002a,b; Myers, 2005]). The characterization objectives have been to assess the risk posed to groundwater of tank waste contaminants in the vadose zone and to develop improved conceptual models (e.g., Davis et al., 2004) of hydrologic and geochemical processes, and of geologic features controlling contaminant migration in the vadose zone. Additionally, recognizing the lack of scientific understanding of deep vadose zone processes, both the USDOE's Office of Environmental Management and Office of Science have supported significant applied and fundamental research on geochemical and hydrologic processes controlling the transport and fate of tank waste residuals in Hanford's vadose zone.

This paper integrates results from field characterization activities and from laboratory research to identify the primary vadose zone geochemical processes that have acted on leaked tank wastes to control their chemical evolution and the mobility of entrained contaminants in the vadose zone. The processes include ion exchange, dissolution-precipitation, abiotic redox transformations, colloid formation and migration, aqueous complexation, surface complexation, and microbiological transformations. Hydrologic processes are integral to contaminant transport and in situ reaction kinetics; they are addressed by Khaleel et al. (2007) and Ward and Zhang (2007) in this issue. First, we provide background information on geochemical reactants in this complex system, including the mineralogy of Hanford's vadose zone sediments, and tank waste chemical composition and thermal characteristics. Then, we illustrate the effects of the above features on waste neutralization, transformation, contaminant retardation, sequestration, and migration, using case studies from field and laboratory campaigns performed to understand the subsurface behavior of different tank waste types and specific contaminants. We conclude by discussing (i) the integration of these processes into reactive transport models and (ii) the remaining critical gaps in scientific understanding of processes and other issues controlling the subsurface fate and transport of tank wastes.

\section{Background}

\section{Subsurface Geology and Mineralogy}

Approximately 30.5 to $122 \mathrm{~m}$ of unconsolidated sediments of Pleistocene and Pliocene age overlie Miocene age tholeiitic basalt flows (Columbia River Basalt Group) at the Hanford Site. The Pleistocene-age Hanford formation (catastrophic flood deposits from glacial Lake Missoula) and Pliocene-age Ringold Formation (overbank deposits from the ancestral Columbia River) are the primary geologic units in the unconsolidated sediments (Fig. 3). The Hanford formation contacts the Ringold Formation at an erosional discontinuity, and occasionally, the intervening Pliocene-age Cold Creek unit consisting of calcified paleosols is found between the two units. Hanford's unconsolidated sediments reach their greatest depths in the central or 200 Area plateau, where the processing facilities and tank farms are located. At these locations the vadose zone is approximately 61 to $85.4 \mathrm{~m}$ in thickness, and the unsaturated sediments override 
Hanford's unconfined aquifer in suprabasalt sediments. The generalized stratigraphy of the Hanford site is shown in Fig. 3 (USDOE, 1988, 2002; Lindsey, 1995, 1996). Considerable variability in the thicknesses and properties of the three primary vadose zone geologic units exist across Hanford's central plateau in both east-west and north-south directions. The general character of these three units is described in Table 1 .

The sand and gravel mineralogy of the Hanford and Ringold formations is similar because of common geologic provenance. Gravel-sized clasts generally consist of $>50 \%$ subangular to subrounded basalt rock fragments (USDOE, 2002). Sand facies generally contain $50 \%$ basaltic lithic fragments and $50 \%$ granitic fragments, whereas silt is typically dominated by quartz, various feldspars, and micas (biotite and muscovite) (Ginder-Vogel et al., 2005; Tallman et al., 1979; Zachara et al., 2002). The clay fraction is remarkably consistent between different vadose zone samples (Knepp, 2002a; Myers, 2005; Zachara et al., 2002) and is dominated by expansible phyllosilicates (smectite), ferroan chlorite (chlinochlore), and mica (both biotite and muscovite) (Fig. 4), with serpentine-group minerals (antigorite and lizardite) also being reported (Ginder-Vogel et al., 2005).

The sediments invariably contain a magnetic, Fe-rich mineral fraction (at $\leq 2$ mass \%) that contains magnetite, ilmenite, $\mathrm{Fe}(\mathrm{II}) / \mathrm{Fe}(\mathrm{III})$ phyllosilicates, and $\mathrm{Fe}(\mathrm{III})$ oxides (ferrihydrite; goethite) (according to X-ray diffraction and transmission Mössbauer spectroscopy). This potentially reactive fraction has not been well studied and is expected to show considerable variation between the Hanford and Ringold formations and specific vadose zone samples from within them. In a study of four $<2.0$-mm size isolates of $\mathrm{U}(\mathrm{VI})$-contaminated, Hanford formation vadose zone sediments from the 300 Area $U$ plume near

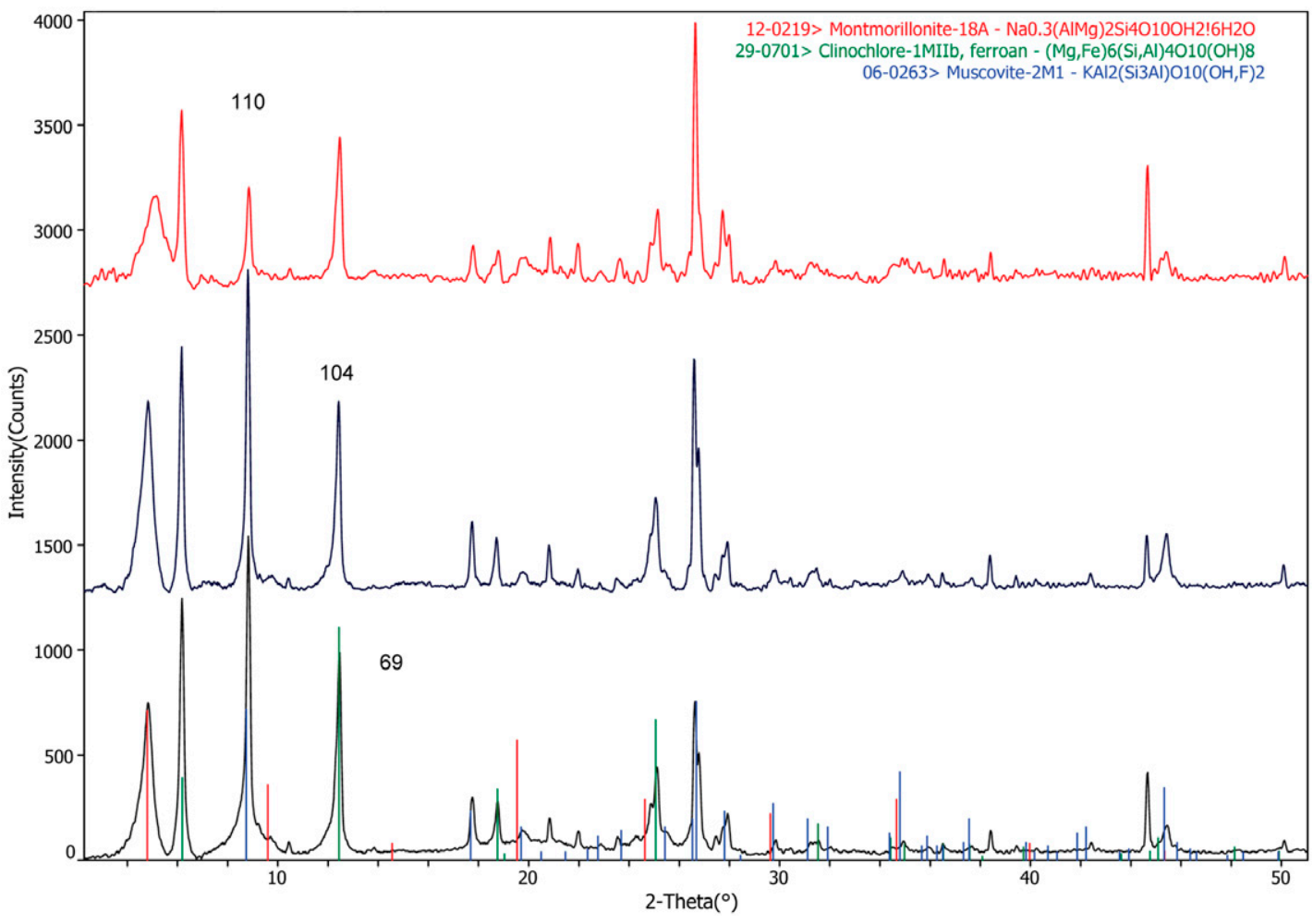

FIG. 4. X-ray diffractograms of the clay-sized fraction $(<2.0 \mu \mathrm{m})$ isolated from deep vadose zone sediments collected beneath the TX tank farm (borehole C3832). Samples 69 and 104 are from the Hanford formation; sample 110 is from the Cold Creek formation.
TABLE 1. Geologic character of the Hanford, Cold Creek, and Ringold formations at the Hanford Site. $†$

\begin{tabular}{|c|c|c|}
\hline Name & Age & Character \\
\hline Hanford formation & Pleistocene & $\begin{array}{l}\text { Catastrophic, flood deposits ranging } \\
\text { from boulder-size gravel to sand, silty } \\
\text { sand, and silt. Sorting increases with } \\
\text { decreasing texture. Common } \mathrm{cm}- \\
\text { scale layers. }\end{array}$ \\
\hline Cold Creek formation & Pliocene & $\begin{array}{l}\text { Pedogenically altered fluvial, eolian, } \\
\text { and/or colluvial deposits. Occasional } \\
\text { pedogenic calcretes. }\end{array}$ \\
\hline Ringold Formation & Pliocene & $\begin{array}{l}\text { Fluvial-lacustrine deposits including } \\
\text { semi-indurated clay, silt, fine- to } \\
\text { coarse-grained sand, and variably } \\
\text { cemented granule to cobble gravel. }\end{array}$ \\
\hline
\end{tabular}

† From Serne et al. (2004a).

the Columbia River, extractable crystalline Fe(III) oxides (dithionite-citrate-bicarbonate [DCB]) varied from 29 to $67 \mu \mathrm{mol}$ $\mathrm{g}^{-1}$ while poorly crystalline $\mathrm{Fe}(\mathrm{III})$ oxide (ammonium oxalate [AmOx]) displayed a range of 48 to $91 \mu \mathrm{mol} \mathrm{g}^{-1}$ (Bond et al., 2007). A deeper vadose zone sediment from the Hanford plateau displayed extractable $\mathrm{Fe}(\mathrm{III})$ concentrations of $37.7 \mu \mathrm{mol}$ $\mathrm{g}^{-1}$ (DCB) and $9.85 \mu \mathrm{mol} \mathrm{g}^{-1}$ (AMOX) (Um et al., 2007). Additional measurements of this type in deeper vadose zone sediments from Hanford's 200 Area plateau are needed as the above data is insufficient to define a representative range of extractable $\mathrm{Fe}(\mathrm{III})$ concentrations.

The total manganese concentration of Hanford sediments is relatively high because of copious mafic/basaltic lithic fragments. However, the $\mathrm{Mn}(\mathrm{III} / \mathrm{IV})$ contents of Hanford sediments that derive from the weathering of the primary mineral pool of $\mathrm{Mn}$ are highly variable (see Zachara et al., 1995, for several examples) and not well characterized. Manganese(III/IV) oxides are strong sorbents and oxidants (Eary and Rai, 1987; Zachara et al., 1995) that may influence the solid-liquid distribution and valence speciation of polyvalent metals and radionuclides in Hanford sediments (e.g., Cr, Co, Tc). Hanford formation sediments are, in general, only modestly weathered because of youthful age, and significant concentrations of $\mathrm{Mn}$ (III/IV) oxides are not expected except under isolated and specific conditions. Consequently, ranges expected for extractable $\mathrm{Mn}(\mathrm{III} / \mathrm{IV})$ in the Hanford vadose zone cannot be defensibly stated at present.

Detrital and pedogenic calcite are consistently observed throughout the vadose 
zone ranging in concentrations from 1 to $5 \%$ and averaging 1.79 mass \% (Serne et al., 2004a). Pedogenic calcite exists in the form of discrete, but infrequent caliche layers $(\sim 25 \mathrm{~cm}$ in thickness) that formed beneath surfaces that were exposed for extended interflood periods during the Pleistocene. These past pedogenic land surfaces are relatively infrequent. A calcite-indurated paleosol (calcrete; 35-45\% calcite) frequently occurs in the Upper Cold Creek unit immediately below the contact with the Hanford formation (Fig. 3; Serne et al., 2004a). All Hanford sediments not impacted by Hanford wastes exhibit a soil water $\mathrm{pH}$ near neutrality because of high dissolved bicarbonate in pore water and the frequent presence of calcite.

Hanford vadose zone sediments exhibit a cation exchange capacity (CEC) that varies strongly with sediment texture and that increases with decreasing particle size (Ward et al., 2006a). The CEC is primarily contributed by fine-grained phyllosilicates (e.g., Fig. 4), including smectite, vermiculite, and mica, that contain fixed charge from isomorphic substitution (Zachara et al., 2002). The weathering of basaltic glass in lithic fragment interiors may also produce smectite-like secondary phases with significant CEC (McKinley et al., 2007). An average CEC value for medium $<2.0-\mathrm{mm}$ Hanford sand with $9.3 \%$ silt and clay content is $40 \mu \mathrm{eq} \mathrm{g}^{-1}$ (Zachara et al., 2004, 2002). Ward et al. (2006a) reported a range of 20 to $240 \mu \mathrm{eq} \mathrm{g} \mathrm{g}^{-1}$ for a variety of $<2.0$-mm Hanford sediments. Many Hanford sediments contain a sizable mass fraction that is $>2.0-\mathrm{mm}$ in size, and CEC values for whole sediment are often calculated (rightly or wrongly) by assuming that the $>2.0-\mathrm{mm}$ fraction has no exchange sites (Serne et al., 2002c; Ward et al., 2006a). Cation exchange capacity values show positive linear correlation with silt and clay content and negative correlation with sand (Ward et al., 2006a). Under natural conditions, the exchanger phase is saturated with a mixture of $\mathrm{Ca}^{2+}, \mathrm{Mg}^{2+}, \mathrm{Sr}^{2+}$, and $\mathrm{Na}^{+}$, with $\mathrm{Ca}^{2+}$ in predominance. The exchanger phase composition is closely linked with the presence of calcite through solubility reaction (McKinley et al., 2007).

\section{Tank Waste Composition}

Each Pu processing scheme (bismuth phosphate, redox, and PUREX) and the uranium recovery process generated a series of three or more waste streams that differed in composition. These, in turn, differed between processing schemes (Anderson, 1990; Gephart and Lundgren, 1996). Waste streams included cladding dissolution wastes, the primary stream with maximum fission products, and start-up and rinse cycle wastes of different sorts. At least 50 different radioactive waste streams are recognized, which have been categorized into 23 or more distinct waste types (Remund et al., 1995). All Hanford tank wastes were initially acidic $\left(\mathrm{HNO}_{3}\right)$ but were overneutralized with $\mathrm{NaOH}$ to high $\mathrm{pH}$ to minimize tank corrosion. Waste compositions changed significantly after initial routing to the tank farms (i) as the waste solutions boiled and self-concentrated, (ii) as wastes were mixed and intentionally condensed through evaporation to maximize storage space that became limited with time, (iii) as atmospheric $\mathrm{CO}_{2}$ was absorbed by high $\mathrm{pH}$ supernate, (iv) as bismuth phosphate $\left(\mathrm{BiPO}_{4}\right)$ wastes were subjected to uranium recovery in the U Plant, and (v) as redox and PUREX wastes were reprocessed in the B Plant to remove heat-generating isotopes ${ }^{137} \mathrm{Cs}$ and ${ }^{90} \mathrm{Sr}$. Because of these operational and chemical complexities, it is dif- ficult to estimate average compositions for different waste types that were lost to the vadose zone.

For all but three of the older, single-shell tanks (SSTs), free liquid tank wastes have now been pumped into newer, doubleshell tanks (DSTs) for storage until final vitrification. Wastes remaining in many of the SSTs contain some interstitial liquids. Wastes from different sources have been mixed in the DSTs and eight general waste types are recognized (Gephart and Lundgren, 1996; Table 2).

To appreciate the chemical complexity and extreme character of these materials, it is helpful to survey the estimated compositions of waste materials released in specific high-volume tank leaks (e.g., Table 3). These three examples span the range in chemical character of Hanford tank wastes. The redox waste leaked from tank SX-108 in 1971 was a caustic $\mathrm{Na}-\mathrm{NO}_{3} / \mathrm{NO}_{2}$ $\mathrm{OH}-\mathrm{Al}(\mathrm{OH})_{4}$ brine that self-concentrated through boiling caused by radioactive decay. The waste had high ionic strength ( $\mathrm{I}=18)$, high solution density $\left(2.09 \mathrm{~g} \mathrm{~cm}^{-3}\right)$, and temperature greater than $100^{\circ} \mathrm{C}$. It was discharged into a vadose zone that was also elevated in temperature because of heat transfer from multiple boiling waste tanks in the 241-SX tank farm (Pruess et

TABLE 2. Waste inventory totals for double-shell tanks. $†$

\begin{tabular}{lc}
\hline \multicolumn{1}{c}{ Waste } & Waste inventory total \\
\hline & $\mathrm{L}$ \\
Dilute noncomplexed waste & $19,394,000$ \\
Double-shell slurry and double-shell slurry feed & $20,829,000$ \\
Concentrated complexant & $15,117,000$ \\
Neutralized current acid waste & $7,086,000$ \\
Concentrated phosphate & $4,160,000$ \\
Dilute complexed waste & $3,528,000$ \\
Neutralized cladding removal waste & $2,979,000$ \\
Plutonium finishing plant sludge and other solids & $2,266,000$ \\
Total & $75,759,000$
\end{tabular}

† Hanlon (1995).

TABLE 3. Tank waste compositions for three of the Hanford Site's largest tank leaks.

\begin{tabular}{|c|c|c|c|}
\hline Tank waste type & $\begin{array}{l}\text { SX-108† redox } \\
\text { waste }\end{array}$ & $\begin{array}{c}\mathrm{BX}-102 \ddagger \\
\text { neutralized } \\
\mathrm{BiPO}_{4} \text { metal } \\
\text { waste }\end{array}$ & $\begin{array}{l}\mathrm{T}-106 \S \mathrm{B}-\mathrm{Plant} \text { isotope } \\
\text { recovery waste }\end{array}$ \\
\hline Leak volume $(\mathrm{L})$ : & 57,539 & 347,000 & 75,700 \\
\hline Temperature $\left(\mathrm{C}^{\circ}\right)$ : & $100(+)$ & 80 & NR \\
\hline $\mathrm{Al}(\mathrm{OH})_{4}^{-}\left(\mathrm{mol} \mathrm{L}^{-1}\right)$ & 3.36 & $5.9 \times 10^{-4}$ & 0.47 \\
\hline $\mathrm{K}^{+}\left(\mathrm{mol} \mathrm{L}^{-1}\right)$ & 0.074 & $2.7 \times 10^{-3}$ & 0.02 \\
\hline $\mathrm{Na}^{+}\left(\mathrm{mol} \mathrm{L}^{-1}\right)$ & 19.6 & 2.92 & 4.34 \\
\hline $\mathrm{OH}^{-}\left(\mathrm{mol} \mathrm{L}^{-1}\right)$ & 5.25 & 0.1 & 0.8 \\
\hline $\mathrm{NO}_{3}^{-}\left(\mathrm{mol} \mathrm{L}^{-1}\right)$ & 5.46 & 0.53 & 1.25 \\
\hline $\mathrm{NO}_{2}^{-}\left(\mathrm{mol} \mathrm{L}^{-1}\right)$ & 4.42 & 0.046 & 0.84 \\
\hline $\mathrm{CO}_{3}^{-}$(TOT) $\left(\mathrm{mol} \mathrm{L}^{-1}\right)$ & 0.032 & 0.643 & 0.18 \\
\hline $\mathrm{HPO}_{4}^{2-}\left(\mathrm{mol} \mathrm{L}^{-1}\right)$ & 0.00 & 0.36 & 0.011 \\
\hline $\mathrm{SO}_{4}^{2-}\left(\mathrm{mol} \mathrm{L}^{-1}\right)$ & 0.028 & 0.23 & 0.089 \\
\hline $\mathrm{CrO}_{4}^{2-}\left(\mathrm{mol} \mathrm{L}^{-1}\right)$ & 0.41 & 0.0016 & 0.043 \\
\hline $\mathrm{UO}_{2}^{2+}\left(\mathrm{mol} \mathrm{L}^{-1}\right)$ & $8.79 \times 10^{-3}$ & 0.114 & 0.003 \\
\hline $\begin{array}{l}\text { Dibutyl phosphate } \\
\quad\left(\mathrm{mol} \mathrm{L}^{-1}\right)\end{array}$ & NET & $\mathrm{NE}$ & $4.84 \times 10^{-2}$ \\
\hline${ }^{137} \mathrm{Cs}^{+}\left(\mathrm{Ci} \mathrm{L}^{-1}\right)$ & $7.71 \times 10^{-1}$ & $1.02 \times 10^{-2}$ & $4.97 \times 10^{-2}$ \\
\hline${ }^{90} \mathrm{Sr}^{2+}\left(\mathrm{Ci} \mathrm{L}^{-1}\right)^{\prime}$ & $1.22 \times 10^{-1}$ & NR & $1.34 \times 10^{-4}$ \\
\hline${ }^{99} \mathrm{Tc}\left(\mathrm{Ci} \mathrm{L}^{-1}\right)$ & $2.27 \times 10^{-4}$ & $9.42 \times 10^{-6}$ & $2.8 \times 10^{-5}$ \\
\hline $\mathrm{Pu}\left(\mathrm{Ci} \mathrm{L}^{-1}\right)$ & $5.33 \times 10^{-4}$ & $8.68 \times 10^{-6}$ & $2.5 \times 10^{-5}$ \\
\hline $\operatorname{Am}\left(\mathrm{Ci} \mathrm{L} \mathrm{L}^{-1}\right)$ & $8.52 \times 10^{-5}$ & NR\# & $\begin{array}{l}1.37 \times 10^{-2} \text { (note other } \\
\text { isotopes especially } \\
\mathrm{Eu}^{154 / 155} \& \mathrm{Se}^{79} \text { ) }\end{array}$ \\
\hline
\end{tabular}

$\dagger$ Jones et al. (2000b)

$\ddagger$ Jones et al. (2001).

$\S$ Jones et al. (2000a)

II NE, not expected.

\# NR, not reported. 
al., 2002). Contaminants in especially high concentration were $\mathrm{CrO}_{4}{ }^{2-},{ }^{137} \mathrm{Cs}^{+}$, and ${ }^{99} \mathrm{Tc}$. The neutralized $\mathrm{BiPO}_{4}$ metal waste released at BX-102 by tank overfilling in 1951 was a concentrated, $80^{\circ} \mathrm{C}$, alkaline solution of $\mathrm{U}(\mathrm{VI})$ dissolved in $\mathrm{Na}-\mathrm{HCO}_{3}$ with $\mathrm{PO}_{4}$ and $\mathrm{SO}_{4}$, and a wide array of fission products. This was an early Hanford waste that had not been subject to uranium recovery. Fluids leaked from tank T-106 were a later Hanford waste (PUREX) that had been subject to isotope recovery in B plant. It contained high levels of $\mathrm{Na}-\mathrm{NO}_{3} / \mathrm{NO}_{2}-\mathrm{OH},{ }^{137} \mathrm{Cs},{ }^{90} \mathrm{Sr}$, and ${ }^{99} \mathrm{Tc}$, and dibutyl phosphate (DBP), an organic complexant. In addition to the constituents in Table 3, B- and T-plant waste contained elevated concentrations of a number of more exotic fission products including ${ }^{79} \mathrm{Se},{ }^{125} \mathrm{Sb},{ }^{151} \mathrm{Sm},{ }^{154 / 155} \mathrm{Eu}$, and multiple isotopes of Pu and Am (Jones et al., 2000a).

\section{Geochemical Processes Influencing Tank Waste Migration in the Vadose Zone}

Approximately 67 single-shell tanks have leaked tank waste into the vadose zone in the 200 Area plateau (Gephart and Lundgren, 1996). Generally, the leak volumes have been small relative to the waste tank volumes. Three of the largest known leaks are reported in Table 3; these range from 57,540 to 347,000 L. Despite these relatively small waste fluid volumes, great concern exists because of the high contaminant concentrations present in the wastes and their extreme chemical and thermal character. The SX-108 spill, for example, released a total of 44,363 $\mathrm{Ci}$ of ${ }^{137} \mathrm{Cs}$ and $13.1 \mathrm{Ci}$ of ${ }^{99} \mathrm{Tc}$ (Knepp, 2002a), while the BX102 overfill event contained an estimated $9430 \mathrm{~kg}$ of U (Knepp, 2002b). T-106 released more than $21,000 \mathrm{Ci}$ of ${ }^{137} \mathrm{Cs}, 21,600$ $\mathrm{Ci}$ of ${ }^{90} \mathrm{Sr}, 32.5 \mathrm{Ci}$ of $\mathrm{Pu}$, and $60 \mathrm{Ci}$ of ${ }^{99} \mathrm{Tc}$ (Myers, 2005). These radioactive and chemical contaminants were released in point source fashion, and groundwater monitoring data indicate that the most mobile of tank waste constituents from these leaks $\left[\mathrm{NO}_{3}{ }^{-},{ }^{99} \mathrm{TcO}_{4}{ }^{-}, \mathrm{CrO}_{4}{ }^{2-}, \mathrm{U}(\mathrm{VI})\right]$ have migrated to groundwater in places (Knepp, 2002a,b; Myers, 2005). However, it is still not certain that the source of all these mobile contaminants in groundwater was tank farm waste because, in many instances, the tank farms are surrounded by cribs, trenches, and pipelines that were used to purposefully dispose of similar contaminantbearing liquids in much larger volumes $\left(>10^{6} \mathrm{~L}\right)$.

A number of drilling and sampling campaigns have placed boreholes directly through the centers of mass of tank waste plumes in the vadose zone (Freeman-Pollard et al., 1994; Knepp, 2002a,b; Myers, 2005; Serne et al., 2002a,b,c,d,e, 2004a,b). These have been challenging sampling campaigns because of limited access; constrained quarters; environmental, health, and safety issues; and the extremely high radioactivity of many samples (e.g., $\sim 10^{8} \mathrm{pCi} \mathrm{g}^{-1}{ }^{137} \mathrm{Cs}$ ). One of these campaigns (Knepp, 2002a; Serne et al., 2002d) used an angled drilling method to access highly radioactive sediment directly beneath leaked tank SX-108. The study of sediments from these boreholes as well as (i) laboratory interaction experiments with tank waste simulants in contact with specimen or synthetic mineral material or pristine sediments and (ii) reactive transport modeling to describe current subsurface contamination profiles or monitoring data from past leak events have provided important insights on the dominant geochemical processes controlling contaminant migration in the Hanford vadose zone. An extensive data and information base has resulted from these and other related Hanford studies that this paper attempts to summarize, integrate, and evaluate with regard to future science needs.

\section{Ion Exchange}

High sodium waste fluids such as those shown in Table 3 are in gross disequilibrium with the sediment exchanger phase that is predominantly saturated with $\mathrm{Ca}^{2+}$ and $\mathrm{Mg}^{2+}$ with minor $\mathrm{Na}^{+}$ and $\mathrm{Sr}^{2+}$. Indigenous exchangeable ions are displaced from the exchanger phase into pore water by mass action at the leading edge of the migrating waste plume (Fig. 5), leading to a distinct ion exchange front of $\mathrm{Ca}^{2+}, \mathrm{Mg}^{2+}$, and $\mathrm{Sr}^{2+}$ that is nearly coincident with unretarded, anionic $\mathrm{NO}_{3}{ }^{-}$. The migration of $\mathrm{Na}^{+}$ is correspondingly attenuated by its adsorption to the sediment exchanger phase. The high concentrations of $\mathrm{Na}$ in tank wastes relative to native pore water cations leads to almost complete saturation of the exchanger phase by waste $\mathrm{Na}^{+}$. The displacement of ion exchangeable $\mathrm{Ca}^{2+}$ can lead to calcite supersaturation and precipitation at the ion exchange front (Wan et al., 2004a,b,c), with an associated decrease in $\mathrm{pH}$ within this zone: $\mathrm{Ca}^{2+}+$ $\mathrm{HCO}_{3}{ }^{-}=\mathrm{CaCO}_{3}(\mathrm{~s})+\mathrm{H}^{+}$. Magnesium-containing phases may also supersaturate in this region (Zhang et al., 2005). The field ion exchange profile beneath SX-115 in Fig. 5 was well described with a reactive transport simulator (FLOTRAN; Lichtner et al., 2004) containing multicomponent ion exchange described by the Gaines-Thomas convention (Sposito, 1981). The timing, volume, and contaminant concentrations of the tank leak were major uncertainties in the modeling.

Ion exchange also serves as the dominant attenuation mechanism for ${ }^{90} \mathrm{Sr}$, a high-yield fission product present in some tank wastes (Table 3). However, the process is actually one of isotopic exchange between contaminant ${ }^{90} \mathrm{Sr}^{2+}$ and the native, concentration excess, stable $\mathrm{Sr}$ isotope pool $\left({ }^{86} \mathrm{Sr}^{2+},{ }^{87} \mathrm{Sr}^{2+}\right)$ that exists as a minor component of the exchanger phase (McKinley et al., 2007). Tracing the mineralogic locations of ${ }^{90} \mathrm{Sr}^{2+}$ adsorption in coarse-textured sediment beneath leaked waste tank B-110 (Knepp, 2002b; Serne et al., 2002a) by digital autoradiography (Zeissler et al., 2001) (Fig. 6) has identified the presence of unique phyllosilicate (saponite) ion exchange domains in the intersticies of basaltic lithic fragments (Fig. 7) that apparently result from the weathering of glass (McKinley et al., 2007). Ion exchange within these lithic fragment interiors strongly limits desorption and further plume migration in otherwise extremely coarse-textured Hanford sediment.

Cesium-137 is a high-energy, gamma-emitting radionuclide $\left(\mathrm{t}^{1 / 2}=30 \mathrm{y}\right)$ that is in high concentration in tank waste supernatant (Table 3). A highly selective ion exchange process occurs for ${ }^{137} \mathrm{Cs}^{+}$on frayed edges and interlamellae of micaceous mineral phases (Fig. 8) —including biotite, muscovite, and vermiculitethat are ubiquitous in Hanford sediment (McKinley et al., 2001; Zachara et al., 2002). Most of the ${ }^{137}$ Cs that currently exists in subsurface sediments beneath leaked single-shell tanks is sorbed and is immobilized by strong ion exchange to and diffusion within these micaceous sorbents (Liu et al., 2003). High electrolyte concentrations (e.g., $>10^{-1} \mathrm{~mol} \mathrm{~L}^{-1}$ ) of strongly sorbing monovalent ions $\left(\mathrm{K}^{+}, \mathrm{Rb}^{+}\right.$, or $\left.\mathrm{NH}_{4}^{+}\right)$are required to remobilize sorbed ${ }^{137} \mathrm{Cs}^{+}$(Liu et al., 2003). A significant research campaign was undertaken to understand why the migration of large amounts of ${ }^{137} \mathrm{Cs}^{+}$was expedited beneath leaked waste tank 

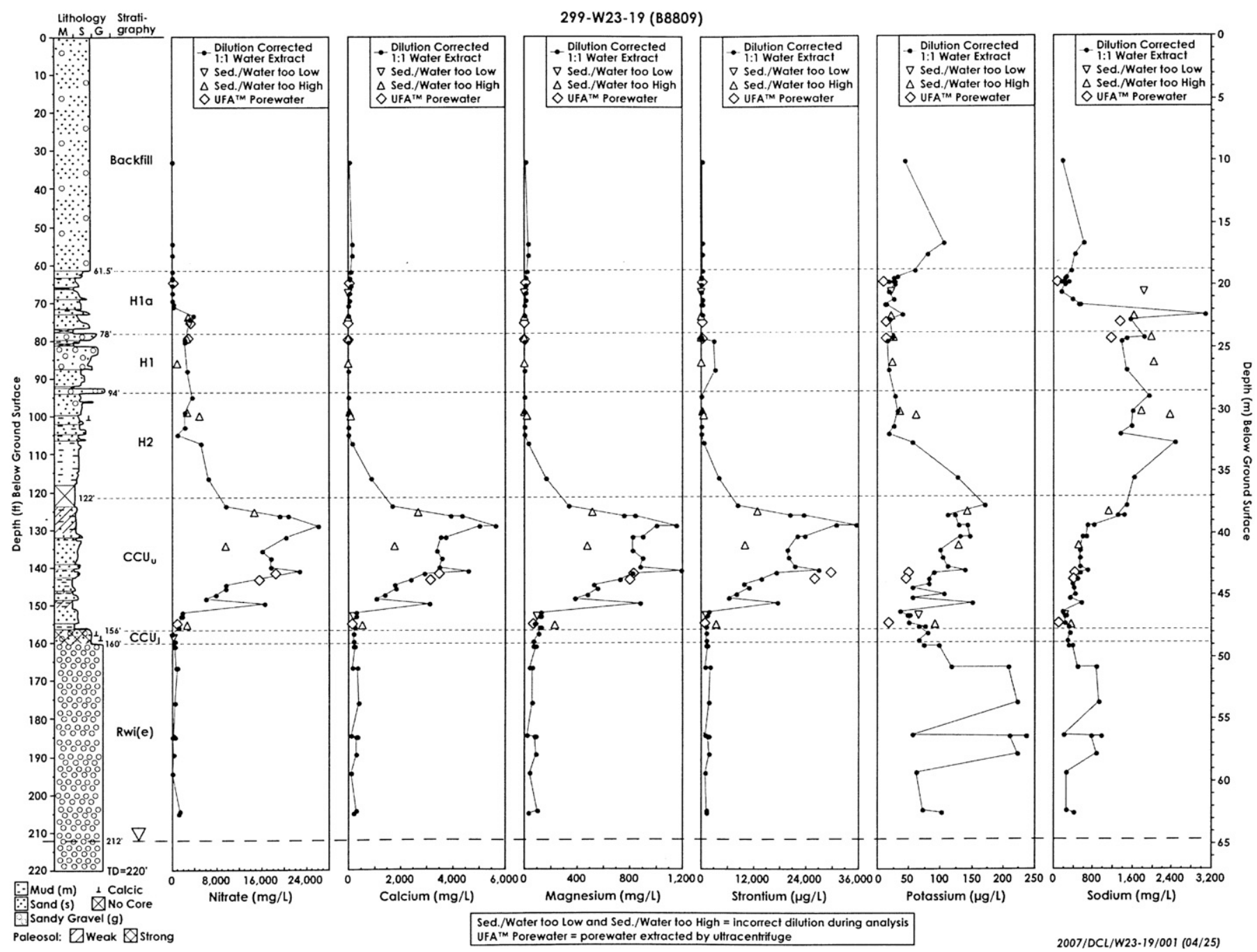

FIG. 5. Depth distribution of water-extractable ions in sediments beneath leaked single-shell tank SX-115. Note the tank waste front at $45.8 \mathrm{~m}$ (150 $\mathrm{ft}$ ) below ground surface. SX-115 released tank waste of intermediate composition. (From Serne et al., 2002e.)

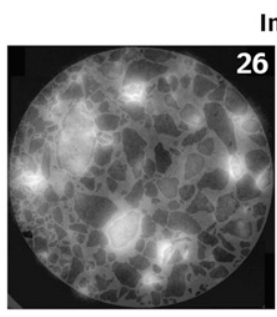

Inverted \& AR Overlain on BSE

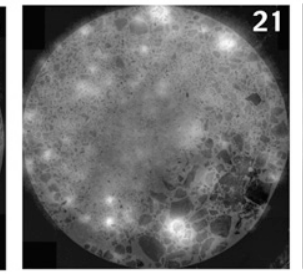

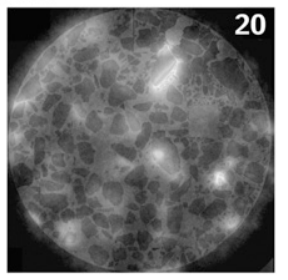

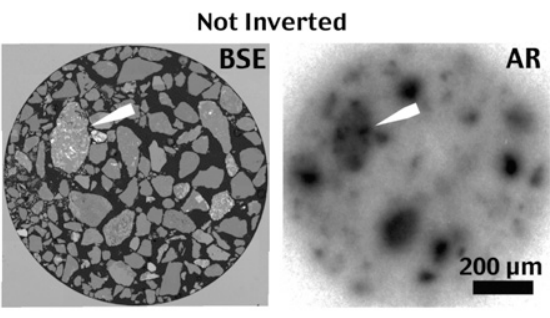

Not Inverted

FIG. 6. Digital autoradiography of ${ }^{90} \mathrm{Sr}$ contaminated sediments from borehole $299-\mathrm{E} 33-46$ (Serne et al., 2002a) near tank B-110; ${ }^{90} \mathrm{Sr}$-containing lithic fragments are white (inverted) or black (not inverted). The backscattered electron (BSE) image shows millimeter-sized lithic fragments (from McKinley et al., 2007).
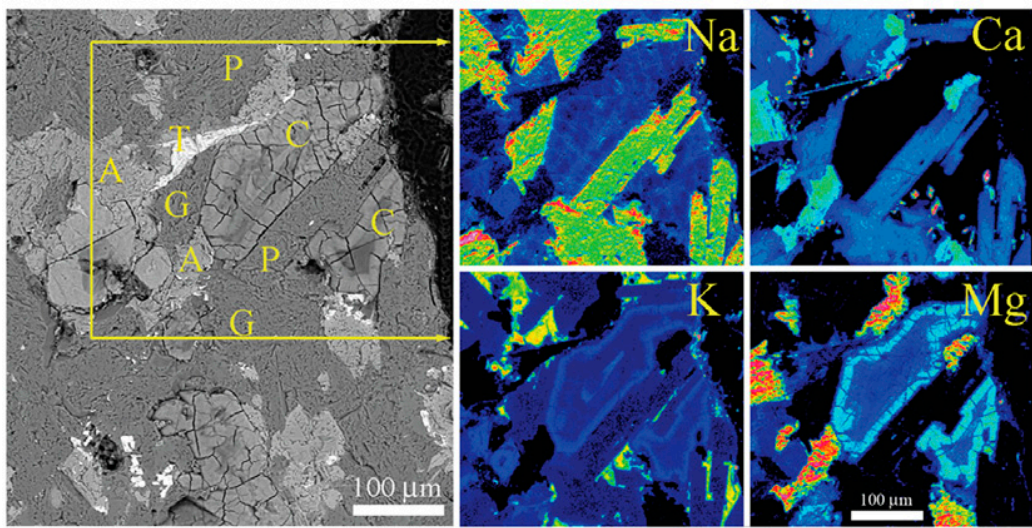

FIG. 7. Chemical composition of ${ }^{90} \mathrm{Sr}$-containing domains from Fig. 6. All are secondary phyllosilicate domains (saponites-C) with characteristic Mg-zonation. (From McKinley et al., 2007.) P, plagioclase; A, augite, G, glass, C, cmectite; $\mathrm{T}$, titanomagnetite. 


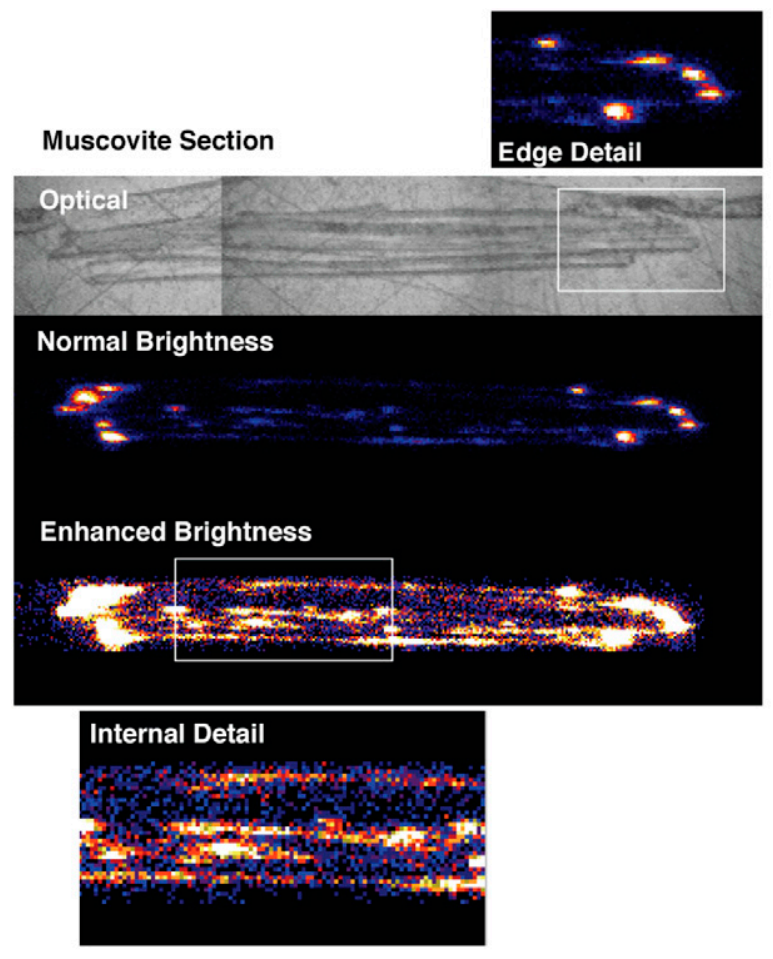

FIG. 8. Distribution of $\mathrm{Cs}^{+}$within muscovite collected from Hanford's $\mathrm{S}$-SX tank farm as measured by synchrotron X-ray fluorescence. Cesium is strongly localized at selected regions on the crystallite edge. (From Liu et al., 2003.)

SX-108 in the S-SX tank farm. It was found that mass action and water activity effects from extremely high $\mathrm{Na}^{+}$concentrations in the self-boiling waste $\left(\sim 19 \mathrm{~mol} \mathrm{~L}^{-1}\right)$ (Liu et al., 2004; Zachara et al., 2002) and enthalpy effects from high subsurface temperature $\left(>70^{\circ} \mathrm{C}\right.$; Liu et al., 2003$)$ were mainly responsible for the anomalous ${ }^{137} \mathrm{Cs}$ behavior. The current subsurface distribution of ${ }^{137} \mathrm{Cs}$ can be well accounted for when these combined effects are considered (Liu et al., 2004).

\section{Dissolution-Precipitation}

Most Hanford tank wastes were intentionally overneutralized to alkaline $\mathrm{pH}$ (Table 3). Some of the waste solutions, such as redox, became concentrated through extended boiling periods driven by radioactive decay of short-lived radioisotopes to yield $\mathrm{NaNO}_{3}$ brines with high $\mathrm{OH}^{-}$(e.g., $5 \mathrm{~mol} \mathrm{~L}^{-1}$, Table 3). Radiolysis in the alkaline waste solutions may have influenced the speciation of polyvalent metals and radionuclides (e.g., ${ }^{99} \mathrm{Tc}$ ) in tank waste with high organic content (Lukens et al., 2001, 2002). These high pH, caustic solutions were extremely reactive when discharged to native, circumneutral Hanford sediments composed of aluminosilicate minerals. In certain cases, tank wastes with residual heat (e.g., $>50^{\circ} \mathrm{C}$ ) from processing operations or radioactive decay leaked into the vadose with ambient temperature, while in other cases, tank wastes were discharged to the vadose zone that had itself been heated by extended waste tank boiling (Liu et al., 2003; Pruess et al., 2002). Elevated temperature accelerates the rate of base-induced $\left(\mathrm{OH}^{-}\right)$hydrolysis of aluminosilicates and certain precipitation reactions. Moreover, the aqueous phase that results from waste-sediment reaction at elevated temperature may become highly supersaturated with various mineral phases as temperatures decrease with transport distance from the waste source.

Laboratory studies to simulate the reaction process of highly alkaline tank waste (e.g., upper range with $\mathrm{pH}>14$ ) with Hanford sediment have identified two primary reaction zones (Qafoku et al., 2004; Wan et al., 2004a,b) that progress hydrologically downgradient from the source of release. The zone nearest the source is dominated by silicate (e.g., quartz) and fine-grained aluminosilcate dissolution reactions that moderate $\mathrm{pH}$ (from $\mathrm{pH} 14$ to $\mathrm{pH}$ 11-12) by hydroxide consumption. Important micaceous sorbents including biotite may also dissolve in this zone (He et al., 2005; Samson et al., 2005). Hydroxide alkalinity is transformed to silica and aluminate alkalinity (Marshal et al., 2004). Below this zone, whose depth is controlled by the volume of tank waste release, exists a $\mathrm{pH}$ neutralization zone $(\mathrm{pH}$ 6.5-10), where protons are released for additional base neutralization by the secondary precipitation of complex suites of zeolitic phases including cancrinite; feldspathoids including sodalite, ettringite, gibbsite; and other unnamed aluminosilicates (Ainsworth et al., 2005; Bickmore et al., 2001; Chorover et al., 2003; Deng et al., 2006; Qafoku et al., 2004; Um et al., 2005; Wan et al., 2004a.b; see Fig. 9). Hydroxide concentration and anion identity/concentration are critical variables determining secondary mineral precipitate morphology and identity. The precipitates exist as both grain coatings (Ainsworth et al., 2005; Bickmore et al., 2001; Qafoku et al., 2004) and suspended colloids in the aqueous phase exhibiting negative surface charge (Marshal et al., 2004). The importance of nitrate is worth noting because in high concentrations, it accelerates the formation of nitrate-bearing aluminosilicate (zeolitic) precipitates in laboratory simulation of weathering fronts (Wan et al., 2004b; Zhang et al., 2005).

Many have speculated that these secondary precipitates may influence tank waste contaminant migration by internal seques-
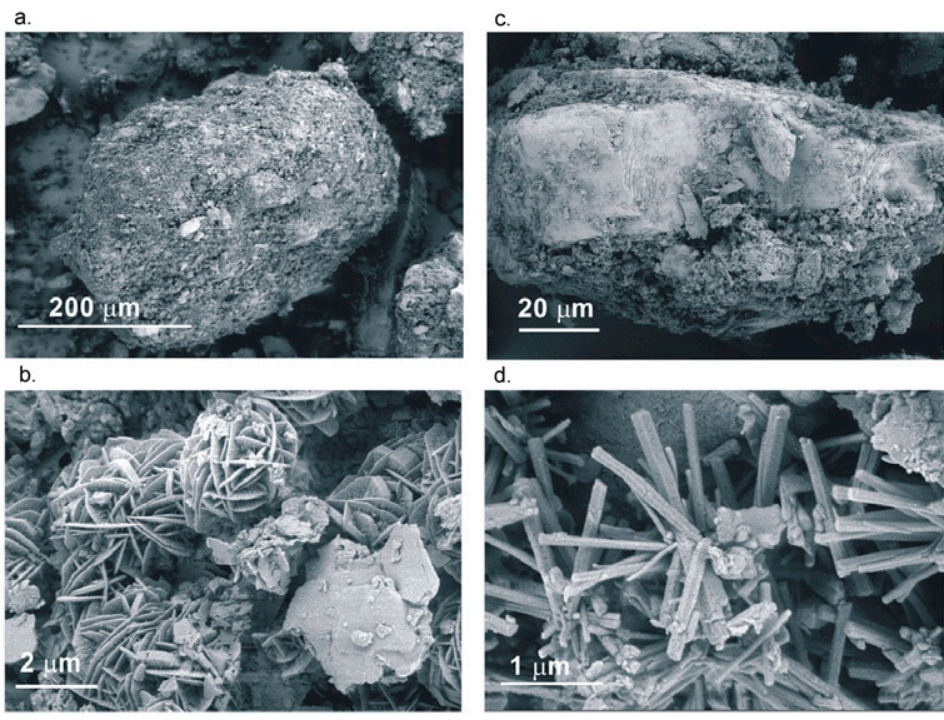

FIG. 9. Secondary feldspathic precipitates resulting from the reaction of $\mathrm{Na}^{+} / \mathrm{NO}_{3}{ }^{-} / \mathrm{OH}^{-}$tank waste simulant with Hanford sediment. The dissolution of primary aluminosilicates and reprecipitation of various secondary phases neutralizes the high pH of tank waste. (From Qafoku et al., 2003.) Reproduced with permission from Environ. Sci. Technol. 2003. 37:3640-3646. Copyright 2003 American Chemical Society. 
tration or surface adsorption. However, these issues have only been partially explored in the laboratory, with variable effects noted in mineral (Catalano et al., 2005; Choi et al., 2005a,b; Chorover et al., 2003; Mon et al., 2005) and sediment systems (Ainsworth et al., 2005; Marshal et al., 2004). Zhuang et al. (2003) observed that ${ }^{137} \mathrm{Cs}^{+}$adsorbed to feldspathic colloids resulting from waste-sediment reaction, but sorption strength was below that of the native micaceous fraction. Ainsworth et al. (2005) observed only minor effects of high-base weathering on ${ }^{137} \mathrm{Cs}^{+}$adsorption by Hanford sediment. Enhanced sorption of $\mathrm{Sr}^{2+}$, apparently driven by coprecipitation processes, has been observed in suspensions of phyllosilicates contacted with alkaline tank waste simulants (Choi et al., 2005a,b).

Mineralogic studies have been performed on field samples collected from boreholes beneath waste tanks that leaked highly alkaline wastes (Knepp, 2002a; Zachara et al., 2004). While these sediments show distinct evidence for alteration in the near-source region (Zachara et al., 2004), they have not shown the high degree of mineral transformation or the distinct morphologies of secondary zeolite and feldspathoid mineral precipitates that have been observed in the laboratory (e.g., Deng et al., 2006). Because of constraints of sampling very near to the tanks themselves, the closest that field samples have been obtained successfully is $1.5 \mathrm{~m}$ from the sides or bottom, and most field samples have been collected no closer than $3 \mathrm{~m}$ from the tanks. In fact, the mineral and crystalline nature of these phases has been very difficult to assess in the field samples because of high associated radioactivity. The differences may result from the use of higher $\mathrm{OH}^{-}$to sediment ratios in the laboratory than actually occurred in the field, or alternatively, that initial zeolites and feldspathoids have transformed to different, more stable phases with environmental exposure. Careful attention needs to be paid to select realistic reactant:sediment ratios when attempting to simulate field-scale waste-sediment interactions in the laboratory. Alternatively, perhaps the zone of intense base-sediment reaction occurs in a volume of sediment no larger than $3 \mathrm{~m}$ distance from the leak events.

\section{Redox Processes}

In its natural state, the Hanford vadose zone contains low volumetric moisture content $(<10 \%)$ because of the semiarid climate. The water unsaturated pore space is generally fully oxygenated because of slow rates of microbial respiration. Most polyvalent contaminants with intermediate redox potentials (e.g., Tc and Cr) released to the Hanford vadose zone in near-neutral or poorly buffered wastewaters, in consequence, remain in the fully oxidized state because the surfaces of potential mineral reductants (e.g., illmenite and magnetite) are passivated by reaction with oxygen or by physical coating with secondary mineral phases such as calcite or Fe(III) oxides (Ginder-Vogel et al., 2005).

One important consequence of the dissolutionprecipitation reactions that are promoted by alkaline tank wastes as described above is the release of redox reactive, structural $\mathrm{Fe}(\mathrm{II})$ that is present in primary mineral phases such as biotite and chlorite (GinderVogel et al., 2005; He et al., 2005; Qafoku et al., 2003; Zachara et al., 2004). Ferrous iron so released may adsorb to mineral surfaces, precipitate as $\mathrm{Fe}(\mathrm{OH})_{2}(\mathrm{~s})$ or other $\mathrm{Fe}(\mathrm{II})$ phases, or migrate with the pore fluid. The ferrous iron can react with (i) dissolved oxygen, lowering Eh, and (ii) oxidized, polyvalent tank waste contaminants such as $\mathrm{CrO}_{4}{ }^{2-}$, causing changes to lower, less-soluble valence states. In laboratory studies, alkaline tank waste simulants dissolved Fe(II) from biotite and Hanford sediments that reduced soluble, weakly adsorbed $\mathrm{CrO}_{4}^{2-}$ to insoluble Cr(III) (Ginder-Vogel et al., 2005; He et al., 2005; Qafoku et al., 2003). Chromate reduction increased with base concentration and ionic strength and was hypothesized in both cases to involve a homogeneous reduction pathway. Field samples from beneath leaked waste tank SX-108 showed an anomalous retardation profile for $\mathrm{Cr}$, which was shown through $\mathrm{X}$-ray absorption near edge structure (XANES) analysis to result from the base-induced reductive immobilization of a portion of the waste $\mathrm{Cr}$ as $\mathrm{Cr}$ (III) (75-31\%) (Zachara et al., 2004; Fig. 10). The extent of reduction decreased with increasing distance from the source as hydroxide was neutralized through mineral reaction. The resulting $\mathrm{Cr}$ (III) remains immobilized in the vadose because of its slow reoxidation rate by molecular oxygen (Zachara et al., 2004) and an apparent lack of sediment-associated $\mathrm{Mn}$ (III/IV) oxides that could function as heterogeneous oxidants (as noted by Eary and Rai, 1987).

Evans et al. (2007) analyzed trace fission oxyanions, including $\mathrm{Mo}, \mathrm{V}$, and $\mathrm{Se}$, in water and acid extracts of a tank waste plume; out of this broader oxyanion analyte suite, only Mo showed evidence for reductive attenuation. Differences in oxyanion behavior result from their variable thermodynamic properties, kinetic pathways of reaction with $\mathrm{Fe}(\mathrm{II})_{\mathrm{aq}}$ and sorbed $\mathrm{Fe}(\mathrm{II})$, and the susceptibility and rate of oxidation of the reduced valence states. Similar laboratory experiments to those of Qafoku et al. (2003) have been performed with the oxyanion ${ }^{99} \mathrm{Tc}(\mathrm{VII}) \mathrm{O}_{4}{ }^{-}$(Hess, personal communication, 2007), a major risk-driving contaminant at Hanford. Technetium-99 exhibits some similarities in

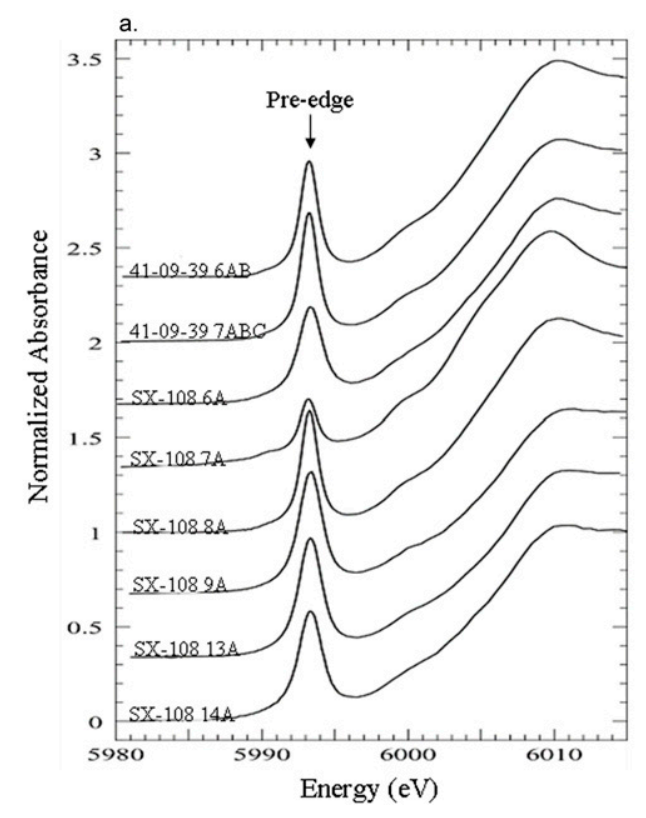

FIG. 10. (a) X-ray absorption near edge structure (XANES) spectra of Cr-contaminated sediment from SX-108 borehole C3082 where the height of the pre-edge feature is proportional to the $\mathrm{Cr}(\mathrm{VI})$ content. (From Zachara et al., 2004.) (b) Synchrotron $\mathrm{X}$-ray fluorescence map of SX-108 sediment 7A, overlain on a backscattered electron micrograph. $\mathrm{Cr}$ concentration increases from green to red. 
redox thermodynamics, reaction mechanisms with $\mathrm{Fe}(\mathrm{II})$, and solubility of oxidized and reduced states to $\mathrm{CrO}_{4}^{-}$(Zachara et al., 2007). It, too, is reduced by Fe(II) liberated by base-induced mineral dissolution, yielding an insoluble $\mathrm{Tc}(\mathrm{IV})$ precipitate. This reduced form, however, apparently reoxidizes rapidly when oxidizing conditions return. Thus, the reductive immobilization process noted for $\mathrm{Cr}$ in association with alkaline tank waste is probably only important for those oxyanions whose reduced species reoxidize slowly.

\section{Colloid Formation and Migration}

The attachment (by adsorption to or precipitation on) of strongly sorbing radionuclides to colloidal-sized materials (1 nm to $1 \mu \mathrm{m}$ ) that are transported by mobile pore fluids is potentially an important transport mechanism (Honeyman, 1999; Kersting et al., 1999; McCarthy and Zachara, 1989; Sen and Khilar, 2006) that needs to be considered for certain contaminants at the Hanford Site. Susceptible contaminants include those of very low solubility (e.g., Am, Pu, Th) or those that strongly adsorb to mineral phases of clay-size (e.g., $<2.0 \mu \mathrm{m}$ ) and below (e.g., ${ }^{137} \mathrm{Cs}^{+}$). Mobile colloids are generated when subsurface water systems experience chemical perturbations that cause relatively rapid, in situ precipitation events or ionic strength induced particle disaggregation (McCarthy and Zachara, 1989; Roy and Dzombak, 1997). These conditions have occurred at Hanford as caustic, saline tank wastes have been neutralized by dissolution-precipitation reactions with surface sediments, and as low ionic strength recharge waters resulting from meteoric water infiltration and infrastructure water losses have migrated behind relatively small volumetric releases of tank wastes causing salinity fronts. Critical questions for the Hanford Site are whether mobile colloid-contaminant associations form and whether such associations are stable against dissociation and filtration during transport through the highly structured vadose zone that is generally, but not always, low in moisture content. Indeed, the importance of colloid-facilitated transport is under debate in the field of environmental science since few studies have clearly shown its importance in the field (Honeyman, 1999).

Flury, Harsh, and colleagues have comprehensively evaluated questions of colloid migration for contaminant ${ }^{137} \mathrm{Cs}^{+}$at the Hanford Site (Chen and Flury, 2005; Chen et al., 2005; Cherrey et al., 2003; Czigany et al., 2005; Flury et al., 2002; Marshal et al., 2004; Zhuang et al., 2003, 2004). The results of these publications are summarized briefly here. The authors found that native colloids are mobilized by salinity fronts from sand-textured Hanford sediments and that feldspathic colloids are formed by alkaline waste-sediment reaction with a maximum observed concentration of $900 \mathrm{mg} \mathrm{L}^{-1}$. Both of these colloid types behave similarly and exhibit net negative charge, form stable colloid suspensions in simulated Hanford pore water for extended time periods, and are readily transported through disturbed, water-saturated Hanford sediment that has been repacked in laboratory columns. Colloid retention increases, and colloid transport decreases, with decreasing water content as a result of colloid retention in water films of variable thickness. Both native and tank waste-induced feldspathic colloids (neo-formed phases) sorb ${ }^{137} \mathrm{Cs}^{+}$and can induce a small amount of colloid-facilitated migration in repacked laboratory columns under water-saturated conditions. However, colloid-associated
${ }^{137} \mathrm{Cs}^{+}$was stripped from this mobile fraction by downgradient stationary sorbents that were present in the sediment in far greater site concentration than present in the fluid phase. The coprecipitation of ${ }^{137} \mathrm{Cs}^{+}$within neo-formed phases may lower its exchangeability and increase its colloidal-facilitated mobility over the case referred to here, where ${ }^{137} \mathrm{Cs}^{+}$was adsorbed onto preformed colloids before introduction to the column system.

Strong adsorption of ${ }^{137} \mathrm{Cs}^{+}$by immobile colloids and clayand silt-sized phyllosilicates, along with the dramatic decrease in colloid transport that parallels water desaturation, leads to the general conclusion that colloid-facilitated migration of ${ }^{137} \mathrm{Cs}^{+}$is unlikely to be important unless water contents and flow rates are locally and temporally increased by snowmelt or episodic artificial recharge (Czigany et al., 2005). Moreover, in situ colloid migration at Hanford may be markedly less than in laboratory repacked columns because of particle filtration by ubiquitous, structured, fine-textured layers as colloids move downward (Blume et al., 2002; Cherrey et al., 2003). Indeed, modeling simulations of $\mathrm{Cs}^{+}$ migration in the S-SX tank farm based solely on chromatographic separation through multicomponent ion exchange to the immobile micaceous fraction of vadose zone sediment showed close agreement to field profiles (Lichtner et al., 2004). Along these same lines, Dai et al. (2005) found no defensible evidence for colloid-enhanced migration of $\mathrm{Pu}$ downgradient of source terms associated with spent nuclear fuel in Hanford's $100 \mathrm{~K}$ basins.

Laboratory studies show that colloid formation can be significant at tank waste plume fronts as high waste $\mathrm{Na}^{+}$displaces $\mathrm{Ca}^{2+}, \mathrm{Mg}^{2+}$, and $\mathrm{Sr}^{2+}$ from the exchanger phase and induces the supersaturation of calcite and other phases (Wan et al., 2004a,c). Calcite precipitation is enhanced with wastes of elevated temperature (a typical occurrence) because of the retrograde solubility of calcite. The colloid load so produced accumulates in the aqueous phase and significantly exceeds the concentrations produced by salinity gradients (Flury et al., 2002; Wan et al., 2004c). The precipitation reactions neutralize and lower $\mathrm{pH}$ at the plume front allowing the supersaturation and precipitation of other phases including uranyl solids (J. Wan, personal communication, 2007), that may also migrate for unknown distances as colloidal material.

\section{Aqueous Complexation}

Synthetic chelating agents including EDTA (ethylenediamine tetraacetic acid), NTA (nitrilotriacetic acid), gluconate, citrate, TBP and DBP (tributyl and dibutyl phosphate), and a variety of others were used for the complexation of target cationic metals during separation processes for $\mathrm{Pu}$, for the selective removal of radionuclides from waste streams, and for decontamination activities. These compounds and their residues ended up in tank wastes and were subject to complex aging and radiolysis reactions during tank waste storage (Toste, 1991; Toste and Lechner-Fish, 1993; Toste et al., 1994). The characterization of these residual organic compounds is extremely difficult because of high radioactivity, but the organic speciation of select tank waste samples has been performed (Campbell et al., 1996, 1998), showing the presence of EDTA, oxalate, glycolate, formate, acetate, and radiolysis products.

The significance of these compounds (primarily EDTA) is that they may form stable anionic aqueous complexes with normally insoluble cationic radionuclides (e.g., $\mathrm{Co}, \mathrm{Pu}$, and 
Am) enhancing their subsurface migration if discharged to the vadose zone. For example, EDTA has mobilized radionuclides to groundwater at shallow waste disposal sites (Balk and Lee, 1994; Means and Alexander, 1981; Means et al., 1978; Olsen et al., 1986). It greatly enhances the solubility of $\mathrm{Pu}(\mathrm{IV})$ at circumneutral pH (Rai et al., 2001), the primary valence state of contaminant $\mathrm{Pu}$ in Hanford sediments. The complexants are slowly degraded by subsurface microorganisms and may therefore persist in ground for extended periods (Bolton and Girvin, 1996; Bolton et al., 1996, 2000; Liu et al., 2001; VanBriesen et al., 2000). Co(II)EDTA ${ }^{2-}$ exhibits complex behavior in circumneutral Hanford vadose zone sediments (Zachara et al., 1995). If small amounts of $\mathrm{Mn}$ oxides are present, the complex is oxidized to the highly stable, kinetically inert, and freely mobile Co(III)EDTA ${ }^{-}$complex that is not adsorbed by Hanford sediment. If Mn oxides are not present, the Co(II)EDTA ${ }^{2-}$ complex slowly degrades through a ligand-induced dissolution reaction with Hanford sediment to yield immobile, sorbed $\mathrm{Co}^{2+}$ and mobile $\mathrm{Al}(\mathrm{III})$ - and $\mathrm{Fe}(\mathrm{III}) \mathrm{EDTA}^{-}$complexes.

Despite the above reports, there is no definitive field evidence that organic complexants have facilitated the migration of tank waste contaminants through the vadose zone at Hanford. Moreover, there are no confirmed reports of the loss of high complexant waste to the Hanford vadose zone. Immobile $239 / 240 \mathrm{Pu}(\mathrm{IV})$ showed anomalously deep migration at T-106 (Freeman-Pollard et al., 1994), and immobile ${ }^{155} \mathrm{Eu}$ (III) demonstrated a significant migration distance in core C4104 from the T tank farm (Serne et al., 2004b). Both of these observations have led to speculation of chelator-facilitated migration. Organic analyses of extracted pore waters from the proximity of T-106 (Serne et al., 2004b), however, detected no chelators or elevated dissolved organic carbon. It is possible that the complexant concentrations were below detection or that they degraded over the 30 -plus years of in-ground contact. Nonetheless, there is no analytical documentation of chelators associated with mobile radionuclides in field samples to substantiate the hypothesis of organic complexant-facilitated migration at the Hanford Site.

The most dramatic evidence for the far-field migration of a metal ion complex occurs with ${ }^{60} \mathrm{Co}\left(\mathrm{t}^{1 / 2}=5 \mathrm{yr}\right)$. As a bare divalent cation, ${ }^{60} \mathrm{Co}^{2+}$ is adsorbed strongly (e.g., log distribution coefficient $\left[K_{\mathrm{d}}\right]\left[\mathrm{mL} \mathrm{g}^{-1}\right]>10^{3}$ ) by Hanford sediment (Zachara et al., 1995) and is effectively immobile. ${ }^{60} \mathrm{Co}$, however, exhibited unretarded migration through the vadose zone beneath the BY cribs soon after the disposal of liquid process effluents from U Plant containing ferrocyanide wastes in 1954-1955 (Hartman, 2000; Thornton and Lindberg, 2002). Elevated concentrations of ${ }^{60} \mathrm{Co}$ with coassociated cyanide $\left(\mathrm{CN}^{-}\right)$, the presumed complexant, have existed in groundwaters downgradient and surrounding the BY cribs from the year of disposal to the present day (Hartman et al., 2005). Low molar concentrations of the mobile complex (e.g., $<10^{-10} \mathrm{~mol} \mathrm{~L}^{-1}$ ) have, however, prevented identification of its identity (structure, stoichiometry, and coordination number) and valence [e.g., $\mathrm{Co}(\mathrm{II})$ or $\mathrm{Co}(\mathrm{III})]$. By analogy to the ferrocyanide complex [Fe(III) $\left.\mathrm{CN}_{6}{ }^{3-}\right]$ used for ${ }^{137} \mathrm{Cs}^{+}$complexation, the ${ }^{60} \mathrm{Co}$ complex may be hexacyanocobaltate $\left[\mathrm{Co}\right.$ (III) $\left.\mathrm{CN}_{6}{ }^{3-}\right]$. Cobalt-60 also shows high mobility (e.g., $K_{\mathrm{d}}\left[\mathrm{mL} \mathrm{g}^{-1}\right] \leq 1$ ), albeit low concentration, in tank waste leaks (e.g., borehole C3831 near TX-107; Serne et al., 2004a), but it is unclear whether its migration is cyanide facilitated.

\section{Surface Complexation and Uranium Migration}

Surface complexation is an adsorption process by which dissolved solutes form complexes with reactive functional groups on mineral surfaces (Davis and Kent, 1990; Stumm, 1992). The surface functional groups are typically hydroxylated metal ion centers on the surfaces of $\mathrm{Fe}, \mathrm{Si}, \mathrm{Al}$, and $\mathrm{Mn}$ oxides, and on the truncated edges of phyllosilicates. Surface complexation may also occur on the surfaces of carbonate minerals, including calcite and phosphates (Cowan et al., 1990; Savenko, 2001; Wu et al., 1991; Zachara et al., 1991). Because it is an adsorption process, surface complexation leads to a reduction in the mobility of solutes that might otherwise be mobile. Surface complexation has been widely studied in the literature, and several surface complexation models exist that compute adsorption and attendant surface speciation (Sposito, 1984). As a general rule, the adsorption of metal cations (e.g., $\mathrm{Co}^{2+}$ ) is low at lower $\mathrm{pH}(\sim 4)$ and increases with increasing $\mathrm{pH}$, whereas the adsorption of metal anions (e.g., $\mathrm{CrO}_{4}{ }^{2-}$ ) is low at high $\mathrm{pH}(\sim 9)$ and increases with decreasing $\mathrm{pH}$. These behaviors result from ionization reactions of the surface functional groups that lead to surface charge development. Outer- (intervening water between the sorbate and absorbent surface) and inner- (no intervening water) sphere surface complexes are identified, with the latter being more strongly bound. The importance of surface complexation for a given sorbate is controlled by (i) the magnitude of its equilibrium constant with surface functional groups, (ii) the total concentration of surface sites present in the sediment, (iii) pore water $\mathrm{pH}$, and (iv) the concentrations of like ions that may compete for surface sites. These, in turn, are dependent on the mineralogy of the sediment, its surface-charging properties, its surface area, and the tank waste composition.

The hexavalent uranyl cation $\left[\mathrm{U}(\mathrm{VI}) \mathrm{O}_{2}{ }^{2+}\right]$ is an important contaminant of Hanford's vadose zone, originating in bismuth phosphate metal waste (Table 3) and numerous other sources (Simpson et al., 2006). The subsurface migration of U(VI) is slowed in certain cases by surface complexation adsorption reactions (Curtis et al., 2006; Gabriel et al., 1998; Kohler et al., 1996). [Note McKinley et al., 2007, on U(VI) precipitation process in the Hanford vadose zone.] Preliminary studies have investigated U(VI) surface complexation reactions in Hanford vadose zone sediments (Barnett et al., 2002; Bond et al., 2007; Um et al., 2007). Experimental difficulties have been encountered because of the coarse-textured, unweathered character of the sediments and the presence of minor calcite. Neither the surface speciation of adsorbed U(VI), the predominant $U(V I)$ sorbents, or plausible surface reaction networks have been definitively identified. Hence, a generalized surface complexation model does not exist for Hanford sediments that is comparable, for example, to that reported for the Naturita uranium mill-tailings site in Colorado (Davis et al., 2004).

The surface complexation of $\mathrm{UO}_{2}{ }^{2+}$ in suspensions of minerals common to the Hanford vadose zone and open to atmospheric $\mathrm{CO}_{2}$ (e.g., ferrihydrite and smectite; Pabalan and Turner, 1997; Pabalan et al., 1998; Prikryl et al., 2001; Waite et al., 1994) shows behavior that is comparable to that observed with $\mathrm{U}(\mathrm{VI})$ adsorption to Hanford vadose zone sediment (Barnett et al., 2002; Dong et al., 2005; Um et al., 2007). By analogy, it is assumed that the same reaction types that occur on these model mineral phases occur in Hanford sediment. With a fixed concen- 
tration of $\mathrm{U}(\mathrm{VI})$ and sorbent, the amount of $\mathrm{U}(\mathrm{VI})$ adsorption increases with increasing $\mathrm{pH}$ at low $\mathrm{pH}$ (3.5-4.0), and decreases above pH 7 (Fig. 11). Surface complexation modeling suggests that the increase in adsorption results from strong surface binding of $\mathrm{UO}_{2}{ }^{2+}$ and $\mathrm{UO}_{2} \mathrm{OH}^{+}$, with weaker surface binding of $\mathrm{UO}_{2}\left(\mathrm{CO}_{3}\right)_{2}^{2-}$ and other carbonate complexes as $\mathrm{pH}$ increases (Pabalan and Turner, 1997; Waite et al., 1994). The decrease in adsorption above $\mathrm{pH} 7$ results from a change in the predominant $\mathrm{U}$ species to higher charged anionic $\left[\mathrm{UO}_{2}\left(\mathrm{CO}_{3}\right)_{3}{ }^{4-}\right]$ and poorly sorbing neutral ones $\left[\mathrm{Ca}_{2} \mathrm{UO}_{2}\left(\mathrm{CO}_{3}\right)_{3}\right.$; Fig. 12; Dong et al., 2005; Fox et al., 2006], and surface ionization that yields increasing negative surface charge with increasing $\mathrm{pH}$ (Waite et al., 1994; Wazne et al., 2003). Surface complexation modeling has been performed on Hanford sediment based on the assumption that poorly crystalline $\mathrm{Fe}(\mathrm{III})$ oxide is the sorbent (Barnett et al., 2002). Although this approximation may eventually prove correct, it has not been documented directly.

The real difficulty in quantifying the surface complexation processes for $\mathrm{U}(\mathrm{VI})$ in Hanford vadose zone sediments results from the natural $\mathrm{pH}$ range of the sediments and the presence of relatively small concentrations of sorbents that are known to strongly adsorb $\mathrm{U}(\mathrm{VI})$. The natural $\mathrm{pH}$ of Hanford vadose zone sediments ranges from approximately 7 to 8.5 . The presence of alkaline tank waste solutions in contaminated regions extends this $\mathrm{pH}$ range to higher values (e.g., $\mathrm{pH} \approx 10$ ) even after waste neutralization occurs through aluminosilicate hydrolysis. This $\mathrm{pH}$ range overlaps the region where $\mathrm{U}(\mathrm{VI})$ surface complexation to mineral surfaces decreases dramatically (Fig. 11 and 12) from changes in aqueous speciation (e.g., carbonate complexation) and surface charge. Consequently, U(VI) adsorption in Hanford sediment is a sensitive consequence of $\mathrm{pH}$, carbonate concentration, and texture that controls surface area and total site concentration (see, e.g., Um et al., 2007). Measurements of U(VI) adsorption to different Hanford sediments vary widely because of differences in these properties. The interplay of these important variables has not been unraveled sufficiently to allow formulation of a workable, generalized surface complexation model that applies to the numerous sediment facies types that exist throughout the Hanford vadose zone, although efforts are currently underway to do so and preliminary results are promising (Um et al., 2007). Moreover, Pleistocene-age Hanford vadose zone sediments (e.g., Hanford formation) are relatively unweathered due to semiarid

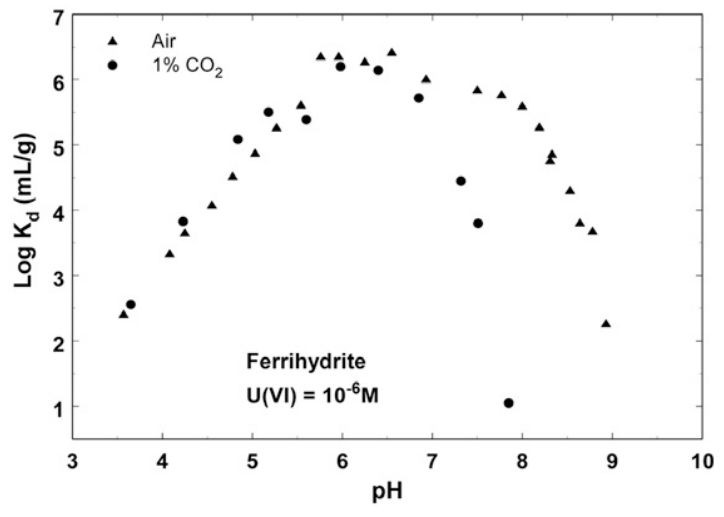

FIG. 11. Adsorption measured by distribution coefficient $\left(K_{d}\right)$ of $1 \mu \mathrm{mol}$ $\mathrm{L}^{-1} \mathrm{U}(\mathrm{VI})$ on $1 \mathrm{mmol} \mathrm{L}^{-1}$ of ferrihydrite, one of the most important subsurface sorbents of uranium. (From Davis et al., 2004.) conditions, and the concentrations of ferrihydrite (e.g., Fig. 11), the strongest and most important sorbent in soils and weathered sediments, are small (e.g., typically $<25 \mu \mathrm{mol} \mathrm{g}^{-1}$ ) and difficult to quantify by extraction (e.g., ammonium oxalate or hydroxylamine hydrochloride) without significant ambiguity.

The ubiquitous presence of calcite in small concentration further complicates our understanding of the surface complexation of $\mathrm{U}(\mathrm{VI})$. Calcite can adsorb the uranyl ion to its surface (Elzinga et al., 2004; Savenko, 2001) and incorporate it within its structure (Kelly et al., 2003; Wang et al., 2005). However, at low concentration (e.g., $<10 \%$ ) calcite appears to form particle coatings that block higher affinity adsorption sites on oxides and phyllosilicates, and release $\mathrm{Ca}^{2+}$ through solubility reaction that forms the poorly sorbing $\mathrm{Ca}_{2} \mathrm{UO}_{2}\left(\mathrm{CO}_{3}\right)_{3}{ }^{0}$ aqueous complex (Dong et al., 2005; Fox et al., 2006). Both of these effects appear to decrease the intrinsic sorptivity of Hanford sediment for $\mathrm{U}(\mathrm{VI})$. In contrast, preliminary observations of contaminant $\mathrm{U}(\mathrm{VI})$ behavior in high calcite (e.g., $>35 \%$ ), paleosol sediments from the Cold Creek unit beneath leaked tank TX-104, indicate that calcite at high concentration may strongly adsorb and immobilize soluble U(VI) in tank waste (Myers, 2005). Ongoing research seeks to resolve the role of calcite as a sorbent when present in Hanford sediment at high concentration.

\section{Oxyanion Migration}

Oxyanions are important components of tank waste resulting from fission (e.g., ${ }^{98,100} \mathrm{MoO}_{4}{ }^{2-},{ }^{79} \mathrm{SeO}_{4}{ }^{2-}$, $\left.101,102,104 \mathrm{RuO}_{4}^{-},{ }^{99} \mathrm{TcO}_{4}^{-}\right)$and/or processing $\left(\mathrm{CrO}_{4}^{2-}\right)$.
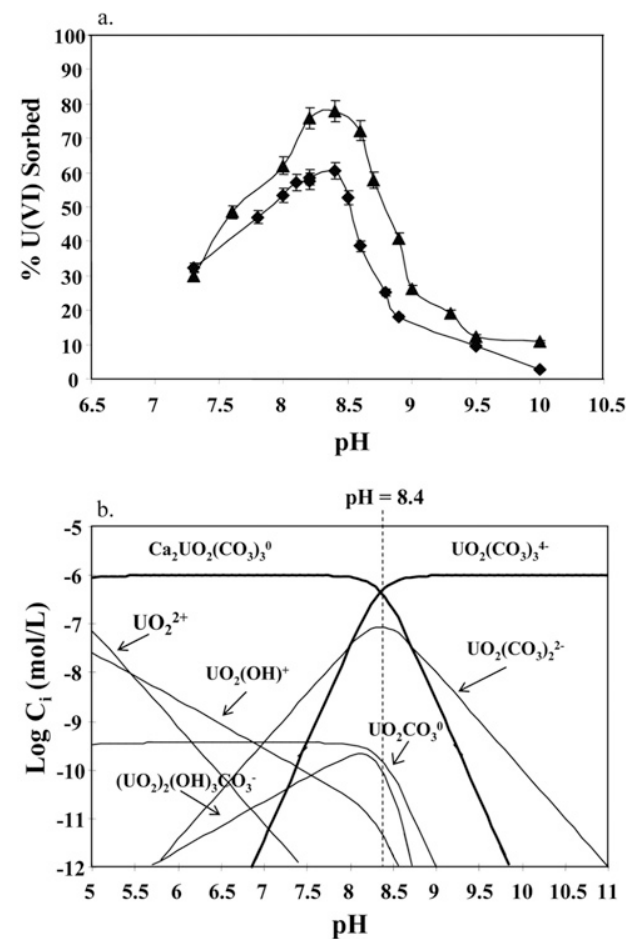

FIG. 12. (a) Adsorption of $\mu \mathrm{mol} \mathrm{L}^{-1} \mathrm{U}(\mathrm{VI})$ on a calcite-containing, deep vadose zone sediment $\left(100 \mathrm{~g} \mathrm{~L}^{-1}\right)$ from Hanford's $200 \mathrm{~A}$ plateau (SSX tank farm) $\downarrow$ = untreated sediment; $\boldsymbol{\Lambda}=$ sediment with calcite removed. (b) Computed aqueous speciation of $\mathrm{U}(\mathrm{VI})$ in calcite-saturated $0.05 \mathrm{~mol} \mathrm{~L}^{-1} \mathrm{NaNO}_{3}$. (From Dong et al., 2005.) Reproduced with permission from Environ. Sci. Technol. 2005. 39:7949-7955. Copyright 2005 American Chemical Society. 
Surface complexation can retard the migration of metallic oxyanions through formation of both inner- and outersphere complexes on $\mathrm{Fe}$ (III) and $\mathrm{Al}(\mathrm{III})$ oxides that carry net positive charge at circumneutral $\mathrm{pH}$ (Davis and Leckie, 1980; Goldberg et al., 1996, 2002; Hayes et al., 1988; Zachara et al., 1989; Zachara et al., 1987). This process, however, appears to be suppressed when tank wastes contact Hanford vadose zone sediment. It is typically observed that in the absence of reduction, the monovalent oxyanions ${ }^{101,102,104} \mathrm{Ru}$ and ${ }^{99} \mathrm{Tc}$ are found at the leading edge of tank waste plumes along with $\mathrm{NO}_{3}{ }^{-}$, with $\mathrm{CrO}_{4}{ }^{2-}$ and 98,100 Mo following close behind (Fig. 13; Evans et al., 2007; Serne et al., 2004b). Technetium-99 [as pertechnetate, $\mathrm{Tc}(\mathrm{VII}) \mathrm{O}_{4}^{-}$] shows virtually no retardation under fully oxidizing conditions
(Kaplan and Serne, 1998; Myers, 2005; Um and Serne, 2005). Consequently, ${ }^{99} \mathrm{Tc}$ and more recently, ${ }^{101,102,104} \mathrm{Ru}$ (Brown et al., 2006) have been used to trace tank waste migration through the vadose zone, and serve as indicators of tank waste contamination in groundwater (Dresel et al., 2002). Technetium-99 is important because it is a significant contributor to overall risk at the Hanford Site (USDOE, 2006). The extreme mobility of all of these anions in tank waste results from low concentrations of anion-adsorbing $\mathrm{Fe}(\mathrm{III})$ oxides in the Hanford vadose zone (the primary potential adsorbent), generally high $\mathrm{pH}$ that encourages negative charge development on amphoteric surfaces, and high concentrations of competing major anions including $\mathrm{NO}_{3}{ }^{-}$and $\mathrm{CO}_{3}^{2-}$ (of waste origin), and $\mathrm{H}_{3} \mathrm{SiO}_{4}^{-}$(from basic mineral

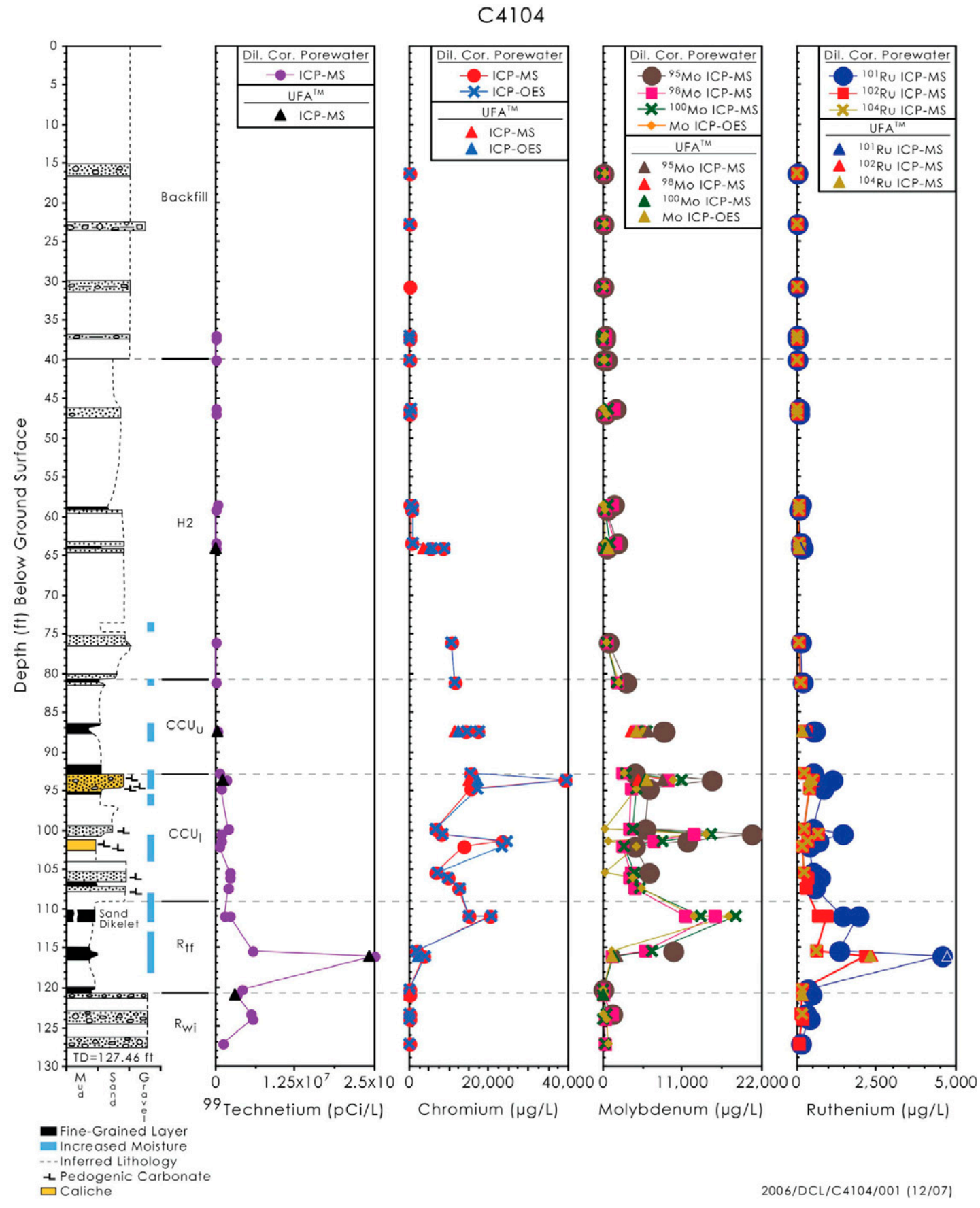

FIG. 13. Derived (Dil. Cor.) and actual (UFA) pore water composition of mobile metals in borehole C4104 collected near T-106. The leading edge of the tank waste plume is defined by ${ }^{99} \mathrm{Tc}$. (From Serne et al., 2004b.) 
hydrolysis) that compete for and saturate available surface sites (Hayes et al., 1988; Zachara et al., 1987).

\section{Microbiological Processes}

Microorganisms may be significant to the long-term fate of tank wastes in the vadose zone because they can mediate a variety of biogeochemical reactions that may influence vadose zone pore water composition and the chemical form, valence, and solidliquid distribution of tank waste contaminants (Fredrickson and Onstott, 2001). For example, subsurface bacteria can transform mobile ${ }^{99} \mathrm{Tc}(\mathrm{VII}) \mathrm{O}_{4}{ }^{-}, \mathrm{U}(\mathrm{VI}) \mathrm{O}_{2}{ }^{2+}$, and $\mathrm{Cr}(\mathrm{VI}) \mathrm{O}_{4}{ }^{2-}$ into immobile, reduced precipitates and denitrify $\mathrm{NO}_{3} / \mathrm{NO}_{2}$ into gaseous, volatile nitrogen forms. Microorganisms populate Hanford's vadose zone (Brockman et al., 1992; Fredrickson et al., 1993; Kieft et al., 1993), with activities and numbers controlled by water content and the concentration of organic matter that is generally sparse. The biogeochemical function and contribution of Hanford's vadose zone microorganisms, however, remains uncharacterized. The activities of subsurface microorganisms are believed to be quite low under ambient conditions and very much limited by low moisture content and nutrient fluxes.

Microorganisms colonize, inhabit, and even flourish in some of the earth's most inhospitable environments (Konhauser, 2007). With this in mind, the microbiological characteristics of one of Hanford's most extreme environments, sediments beneath leaked waste tank SX-108 (C3082), were investigated (Fredrickson et al., 2004). This borehole penetrated a tank waste plume in the vadose zone that received caustic, saline, and highly radioactive redox waste (Table 3). Residual heat in the core of the plume was high when the borehole was drilled in $2001\left(\sim 70^{\circ} \mathrm{C}\right.$ at $19.8 \mathrm{~m}$ below ground surface). This same region experienced temperatures in excess of $100^{\circ} \mathrm{C}$ with steam recirculation at the time of waste spillage in 1962 because of boiling redox waste throughout the tank farm (Pruess et al., 2002). The discharged waste contained large amounts of short-lived radioisotopes (e.g., ${ }^{106} \mathrm{Ru}$, ${ }^{144} \mathrm{Ce},{ }^{147} \mathrm{Pm}$, and others; Jones et al., 2000b) in addition to ${ }^{137} \mathrm{Cs}$ that presented a significant dose to subsurface organisms.

Despite the incredibly harsh thermal, chemical, and radiologic regime beneath tank SX-108, low concentrations $\left(\leq 10^{5}\right.$ bacteria per gram of sediment) of viable microorganisms were recovered from 9 of 16 core samples studied (Table 4). These numbers may underestimate the microorganism population because of the limitations of cultivation-based methods (Amann et al., 1995). No correlation between moisture content or sediment radiation level $\left({ }^{137} \mathrm{Cs}\right)$ was observed (Table 4). Organisms were cultured from waste-impacted sediment that appeared "bone-dry" (e.g., sediments 4 and 10). The cultures obtained (Table 5) were dominated by common dry-soil dwelling, Grampositive microorganisms, most closely related to Arthrobacter species that are known to be good survivors of stressful environments. Two isolates from a high radiation sample containing $>20 \mu \mathrm{Ci} \mathrm{g}^{-1}$ of ${ }^{137} \mathrm{Cs}$ were closely related to radiation tolerant Deinococcus radiodurans (Fig. 14) and were able to survive high doses of applied radiation $(20 \mathrm{kGy})$. Activity measurements on the sediments indicated that the cells were mostly inactive or dormant under the current conditions of low moisture and high salinity. This community could increase in size and activity significantly, with unknown implications to contaminant solubility, if the moisture content were to increase through recharge.
TABLE 4. Culturable bacteria observed in tank SX-108 sediments.

\begin{tabular}{lcccc}
\hline Sample ID & Depth & ${ }^{137} \mathrm{Cs}$ & $\begin{array}{c}\text { Water } \\
\text { content }\end{array}$ & $\begin{array}{c}\text { Number of } \\
\text { bacteria }\end{array}$ \\
\hline 1 & $\mathrm{~m}(\mathrm{ft})$ & $\mathrm{pCi} \mathrm{g}^{-1}$ & $\%$ & log gram $^{-1}$ \\
3 & $16.61(54.48)$ & $3.06 \mathrm{E}+06$ & 4.3 & 4 \\
4 & $20.50(67.27)$ & $1.95 \mathrm{E}+07$ & 2.8 & $\mathrm{bd}+$ \\
5 & $21.80(71.51)$ & $1.38 \mathrm{E}+06$ & 2.8 & 3.7 \\
6 & $23.08(75.73)$ & $6.52 \mathrm{E}+06$ & 4.7 & $\mathrm{bd}$ \\
7 & $24.37(79.94)$ & $5.31 \mathrm{E}+07$ & 3.7 & $\mathrm{bd}$ \\
8 & $25.64(84.13)$ & $2.14 \mathrm{E}+07$ & 6.2 & 3.2 \\
9 & $26.92(88.32)$ & $5.55 \mathrm{E}+05$ & 6 & $\mathrm{bd}$ \\
10 & $28.19(92.48)$ & $1.71 \mathrm{E}+02$ & 2.4 & 2.6 \\
11 & $29.46(96.64)$ & $4.51 \mathrm{E}+02$ & 1.9 & 2.1 \\
12 & $30.80(101.04)$ & $9.12 \mathrm{E}+02$ & 3.2 & $\mathrm{bd}$ \\
13 & $31.98(104.92)$ & $3.37 \mathrm{E}+02$ & 21.4 & 2.7 \\
14 & $34.48(113.14)$ & $5.21 \mathrm{E}+02$ & 7.6 & $\mathrm{bd}$ \\
15 & $36.97(121.3)$ & $8.37 \mathrm{E}+02$ & 12 & $\mathrm{bd}$ \\
16 & $39.45(129.44)$ & $5.92 \mathrm{E}+02$ & 17.4 & 2.1 \\
17 & $41.92(137.54)$ & $9.79 \mathrm{E}+01$ & 7.5 & 3.3 \\
\hline
\end{tabular}

†bd, below detection.

\section{Reactive Transport Modeling}

Geochemical and biogeochemical processes of the types described above can be simulated within multicomponent, reaction-based reactive transport models (Steefel et al., 2005) that synthesize mineralogic, water chemical, hydrologic, geologic, and if necessary, biologic and biogeochemical details of the subsurface system. The resulting models can be used to match historic or current subsurface contamination distribution profiles or to predict future contaminant migration and plume evolution. Different processes are integrated through their influence on a common set of chemical components that are described using a series of mass action relationships termed a reaction network. This way to describe the chemical or biochemical contribution to the retardation factor (Freeze and Cherry, 1979) as a function of system chemical or biologic components is in contrast with the "constant- $K_{\mathrm{d}}$ " approach that has been the mainstay of performance assessment modeling for regulatory compliance (Bethke and Brady, 2000; Steefel et al., 2005).

The reaction-based approach has extensive conceptual model and parameter requirements (Davis et al., 2004) that can be time consuming or just plain difficult to determine, but an appropriately parameterized reaction network can accurately describe complex systems with chemical and biogeochemical change, gradients, multiple processes, and kinetic phenomena. Such an approach can reduce modeling uncertainty because

TABLE 5. Phylogeny of selected tank SX-108 cultures.

\begin{tabular}{|c|c|c|}
\hline Isolate ID & Phylogeny & $\begin{array}{c}\text { GenBank accession } \\
\text { number }\end{array}$ \\
\hline$\overline{1 b-1}$ & Arthrobacter globiformus & M23411 \\
\hline $1 c-1$ & Arthrobacter oxydans & AJ243423 \\
\hline $4 a-4$ & Rhodococcus corynebacteroides & X80615 \\
\hline $4 b-2$ & Staphylococcus warneri & AJ223451 \\
\hline $4 b-3$ & Nocardioides plantarum & Z78211 \\
\hline $7 b-1$ & Deinococcus radiodurans & Y11332 \\
\hline $9 c-3$ & Blastobacter sp. Str. BF10 & AJ223453 \\
\hline $10 c-2$ & Sphingomonas sp. Str. Koll-1 & AJ224938 \\
\hline $12 a-1$ & Pseudomonas sp. Str. BRW3 & AF025351 \\
\hline $12 b-1$ & Pseudomonas sp. Str. BRW3 & AF025351 \\
\hline $15 a-1$ & Terrabacter tumescens & X83812 \\
\hline $17 a-1$ & Arthrobacter aurescens & X83405 \\
\hline $17 a-2$ & Arthrobacter oxydans & AJ243423 \\
\hline $17 a-3$ & Pseudomonas sp. Str. BRW3 & AF025351 \\
\hline $17 b-1$ & Arthrobacter pascens & X80740 \\
\hline
\end{tabular}




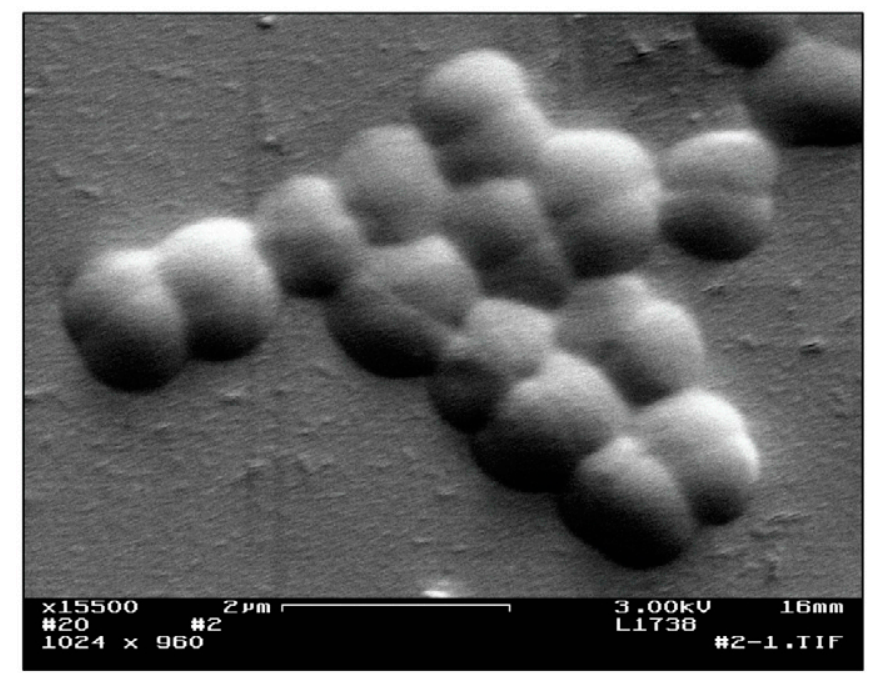

FIG. 14. Scanning electron micrograph of radiation-resistant bacteria Deinoccus radiodurans isolated from sediments collected from beneath leaked single-shell tank SX-108.

spatial and temporal variations in system chemical, mineralogic, surface chemical, and microbiologic properties and processes can be explicitly taken into account. The approach does require that reaction networks be well defined through experimentation and that the subsurface domain to be modeled is adequately characterized in terms of process-controlling properties. Valuable Hanford examples of this approach include the modeling of ${ }^{137} \mathrm{Cs}^{+}$migration (Lichtner et al., 2004; Steefel et al., 2003; Zachara et al., 2002) and tank waste neutralization (Wan et al., 2004a; Wan et al., 2004b; Wan et al., 2004c; Zhang et al., 2005). The "constant- $K_{\mathrm{d}}$ " approach is more simple to parameterize unless a response surface is developed, but it can be inconsistent with the geochemical nature of the retardation process and with laboratory and field behavior/observations through its assumption of linear distribution (Liu et al., 2004; Yeh and Tripathi, 1989; Zhu, 2003).

Debate exists in the literature over which of the two modeling approaches (reaction-based or constant- $K_{\mathrm{d}}$ ) are the most practical to forecast contaminant migration and future behavior (Bethke and Brady, 2000; Brady and Bethke, 2000; Steefel et al., 2005; Zhu, 2003). This same debate occurs at Hanford regarding the modeling of tank waste residuals in the vadose zone. However, the $K_{\mathrm{d}}$ approach is completely inappropriate for the early stages of tank waste-sediment interaction, where kinetically controlled dissolution-precipitation reactions occur in response to a gross state of disequilibrium between mineral solids and waste fluids, or where solubility reactions control desorption under variably saturated conditions (Liu et al., 2004). However, $K_{\mathrm{d}}$ is a useful concept that can be integrated into nonequilibrium, reactive transport calculations for meaningful field application (Qafoku et al., 2005).

\section{Additional Needs and Opportunities}

The research summarized here demonstrates that considerable knowledge regarding the geochemical behavior of Hanford tank waste in the vadose zone has been gained over the last $10 \mathrm{yr}$ through field characterization, laboratory studies with tank-waste contaminated sediments and model mineral-tank waste systems, and reactive transport modeling. It has been observed that most tank wastes released to the vadose zone have reacted with subsurface sediments to reach "steady-state"-like conditions governed by long-term processes because of the length of time that they have been in ground. Many contaminants in tank waste have been strongly retarded by adsorption and precipitation reactions $(\mathrm{Cs}, \mathrm{Pu}, \mathrm{Am}, \mathrm{Eu})$, while others have remained mobile $(\mathrm{Mo}, \mathrm{Ru}$, $\mathrm{Se}, \mathrm{Tc})$. Still others show variable, waste-specific behavior ( $\mathrm{Sr}$, $\mathrm{Cr}$, and $\mathrm{U}$ ) that is closely tied to evolving pore water chemistry and, for $\mathrm{Cr}$, temporal redox conditions. The temperature of in-ground tank waste has moderated by heat exchange with the mineral fraction, and high basicity has been neutralized through mineral hydrolysis and secondary mineral precipitation. Rapid initial kinetic reactions have approached completion, while slower ones have continued in response to water drainage, chemical gradients between particle interiors and exteriors, and mineral transformations of metastable phases.

One of many important future science challenges for Hanford's tank farms is to accurately project the future migration potential of tank waste residuals in the deep vadose zone and the risks posed by mobile contaminants to groundwater. Such projections provide the basis for remedial action decisions and for the development and testing of appropriate remediation strategies. The following fundamental geochemical science needs for the Hanford vadose zone are deemed critical to that end.

- Microscopic chemical speciation, mineral residence, and spatial location of reactive, semimobile contaminants (e.g., U and $\mathrm{Cr}$ ) in deep vadose zone plumes originating from different tank waste types.

- New understanding of the adsorption process of U(VI) to deep vadose zone sediments of variable texture and calcite content over the $\mathrm{pH}$ range of 7 to 10 , and better-linked aqueous-surface speciation models and associated parameters for reactive transport calculations.

- Effects of low and variable water saturation on contaminant desorption (or dissolution) and adsorption rates of weakly [e.g., ${ }^{99} \mathrm{Tc}(\mathrm{VII}) \mathrm{O}_{4}^{-}$] and more strongly (but variably) sorbing $[\mathrm{U}(\mathrm{VI})]$ contaminants for sediment textures ranging from gravel to silt.

- Characterizing long-term contaminant sequestration (including the nature of products formed and their kinetic reversibility) resulting from slow subsurface processes, including microbiologic activity, microscopic transport and intragrain reaction, and mineralogic transformation reactions of metastable phases (aluminosilicates and feldspathoids).

- Reactions controlling pore water composition in different lithologic units and facies types at different water contents and times, and strategies to simulate and predict the composition.

- Mass transfer processes controlling apparent reaction rates, contaminant distributions, and advective transport at different scales ranging from macroscopic to mesoscopic, causal factors, and modeling strategies.

While this paper has emphasized geochemical processes that control the migration of tank wastes in Hanford's vadose zone, water migration is the essential transport vector that controls the migration pathway and the nature and properties of the sediments to which the waste fluids are brought in contact with for geochemical reaction. As for geochemical reaction, the understanding of unsaturated water migration combined with 
geochemical reaction through Hanford's geologically complex vadose zone has dramatically improved over the last $10 \mathrm{yr}$ (Ward et al., 2006a,b)], along with recognition of the important role of thin, fine-grained sediment layers in inducing horizontal anisotropy and lateral water flow (Pace et al., 2004; Ward et al., 2006a,b). Improved hydrologic models have resulted (Raats et al., 2004; Zhang et al., 2003) that when coupled with geochemical models for the processes described herein and as may be evaluated in future research, hold great promise for more accurate and realistic predictions of the future migration of tank waste residuals in Hanford's vadose zone.

\section{ACKNOWLEDGmentS}

This review manuscript was written primarily with funds provided by U.S. Department of Energy's Office of Biological and Environmental Research (OBER), Environmental Remediation Sciences Division (ERSD) through the Hanford Science Linkage Project. Much of the data collection and research described herein was supported by the Hanford Tank Farm Vadose Zone Project managed by CH2M HILL Hanford Group, Inc., and funded by the USDOE Office of River Protection (ORP); the Groundwater/Vadose Zone Science and Technology Project funded by the USDOE Richland Operations Office; and by ERSD's former Environmental Management Sciences Program (EMSP). The authors thank three anonymous reviewers for their helpful and insightful comments that improved the manuscript, and David Lanigan of PNNL for his assistance in figure preparation. PNNL is operated for the USDOE by Battelle.

\section{References}

Ainsworth, C.C., J.M. Zachara, K. Wagnon, S. McKinley, C. Liu, S.C. Smith, H.T. Schaef, and P.L. Gassman. 2005. Impact of highly basic solutions on sorption of $\mathrm{Cs}^{+}$to subsurface sediments from the Hanford Site, USA. Geochim. Cosmochim. Acta 69(20):4787-4800.

Amann, R., W. Ludwig, and K.-H. Schleifer. 1995. Phylogenetic identification and in situ detection of individual microbial cells without cultivation. Microbiol. Rev. 59:143-169.

Anderson, J.D. 1990. A history of the 200 Area tank farms. WHC-MR-0132. Westinghouse Hanford Company, Richland, WA.

Balk, M., and K. Lee. 1994. Transport of radioactive solutes in the presence of chelating agents. Ann. Nucl. Energy 21(2):81-96.

Barnett, M.O., P.M. Jardine, and S.C. Brooks. 2002. U(VI) adsorption to heterogeneous subsurface media: Application of a surface complexation model. Environ. Sci. Technol. 36:937-942.

Bethke, C.M., and P.V. Brady. 2000. How the Kd approach undermines ground water cleanup. Ground Water 38:435-443.

Bickmore, B.R., K.L. Nagy, J.S. Young, and J.W. Drexler. 2001. Nitratecancrinite precipitation quartz sand in simulated Hanford tank solutions. Environ. Sci. Technol. 35:4481-4486.

Blume, T., N. Weisbrod, and J.S. Selker. 2002. Permeability changes in layered sediments: Impact of particle release. Ground Water 40:466-474.

Bolton, H., Jr., and D.C. Girvin. 1996. Effect of adsorption on the biodegradation of nitrilotriacetate by Chelatobacter heintzii. Environ. Sci. Technol. 30:2057-2065.

Bolton, H., Jr., D.C. Girvin, A.E. Plymale, S.D. Harvey, and D.J. Workman. 1996. Degradation of metal-nitrilotriacetate (NTA) complexes by Chelatobacter heintzii. Environ. Sci. Technol. 30:931-938.

Bolton, H., Jr., L. Xun, and D.C. Girvin. 2000. Biodegradation of synthetic chelating agents. p. 363-383. In D.R. Lovley (ed.) Environmental microbe-metal interaction. ASM Press, Washington, DC.

Bond, D.L., J.A. Davis, and J.M. Zachara. 2007. Uranium(VI) release from contaminated vadose zone sediments: Estimation of potential contributions from dissolution and desorption. p. 379-420. In M.O. Barnett and D.B. Kent (ed.) Adsorption of metals by Geomedia II. Academic Press, San Diego, CA.

Brady, P.V., and C.M. Bethke. 2000. Beyond the Kd approach. Ground Water 38:321-322.

Brockman, F.J., T.L. Kieft, J.K. Fredrickson, B.N. Bjornstad, S.-M. Li, W. Spangenburg, and P.E. Long. 1992. Microbiology of vadose zone paleosols in south-central Washington State. Microbiol. Ecol. 23:279-301.

Brown, C.F., P.E. Dresel, K.N. Geiszler, and O.T. Farmer. 2006. Precise ruthenium fission product isotopic analysis using dynamic reaction cell inductively coupled plasma mass spectrometry (DRC-ICP-MS). J. Anal. At. Spectrom. 21(9):955-962.

Campbell, J.A., A.K. Sharma, S.A. Clauss, G.M. Mong, and D.L. Bellofatto. 1998. Organic speciation of AX-102, BX-104, C-104, C-201, and C-202 tank wastes. Pacific Northwest National Laboratory, Richland, WA.

Campbell, J.A., K.L. Wahi, S.A. Clauss, K.E. Grant, V. Hoopes, G.M. Mong, J. Rau, and R. Steele. 1996. Organic tank safety program: Advanced organic analysis FY1996 progress report. Pacific Northwest National Laboratory, Richland, WA.

Catalano, J.G., J.A. Warner, and G.E. Brown, Jr. 2005. Sorption and precipitation of $\mathrm{Co}(\mathrm{II})$ in Hanford sediments and alkaline aluminate solutions. Appl. Geochem. 20:193-205.

Chen, G., and M. Flury. 2005. Retention of mineral colloids in unsaturated porous media as related to their surface properties. Colloids Surf. Physicochem. Eng. Aspects 256:207-216.

Chen, G., M. Flury, and J.B. Harsh. 2005. Colloid-facilitated transport of cesium in variably saturated Hanford sediments. Environ. Sci. Technol. 39:3435-3442.

Cherrey, K.D., M. Flury, and J.B. Harsh. 2003. Nitrate and colloid transport through coarse Hanford sediments under steady state, variably saturated flow. Water Resour. Res. 39(6):1165-1174.

Choi, S., M.K. Amistadi, and J. Chorover. 2005a. Clay mineral weathering and contaminant dynamics in a caustic aqueous system: I. Wet chemistry and aging effects. Geochim. Cosmochim. Acta 69(18):4425-4436.

Choi, S., G. Crosson, K.T. Mueller, S. Seraphin, and J. Chorover. 2005b. Clay mineral weathering and contaminant dynamics in a caustic aqueous system: II. Mineral transformation and microscale partitioning. Geochim. Cosmochim. Acta 69(18):4437-4451.

Chorover, J., S. Choi, M.K. Amistadi, K.G. Karthikeyan, G. Crosson, and K.T. Mueller. 2003. Linking cesium and strontium uptake to kaolinite weathering in simulated tank waste leachate. Environ. Sci. Technol. 37:2200-2208.

Cowan, C.E., J.M. Zachara, and C.T. Resch. 1990. Solution ion effects on the surface exchange of selenite on calcite. Geochim. Cosmochim. Acta 54:2223-2234.

Curtis, G.P., J.A. Davis, and D.L. Naftz. 2006. Simulation of reactive transport of uranium(VI) in groundwater with variable chemical conditions. Water Resour. Res. 42:W04404, doi:10.1029/2005WR003979.

Czigany, S., M. Flury, and J.B. Harsh. 2005. Colloid stability in vadose zone Hanford sediments. Environ. Sci. Technol. 39:1506-1512.

Dai, M., K.O. Buesseler, and S.M. Pike. 2005. Plutonium in groundwater at the 100K-Area of the U.S. DOE Hanford Site. J. Contam. Hydrol. $76: 167-189$

Davis, J.A., and D.B. Kent. 1990. Surface complexation modeling in aqueous geochemistry. p. 177-260. In M.F. Hochella, Jr. and A.F. White (ed.) Mineral-water interface geochemistry. Reviews in Mineralogy 23. Mineralogical Society of America, Washington, DC.

Davis, J.A., and J.O. Leckie. 1980. Surface ionization and complexation at the oxide/water interface: III. Adsorption of anions. J. Colloid Interface Sci. 74:32-43.

Davis, J.A., D.E. Meece, M. Kohler, and G.P. Curtis. 2004. Approaches to surface complexation modeling of uranium(VI) adsorption on aquifer sediments. Geochim. Cosmochim. Acta 68(18):3621-3641.

Deng, Y., J.B. Harsh, M. Flury, J.S. Young, and J.S. Boyle. 2006. Mineral formation during simulated leaks of Hanford waste tanks. Appl. Geochem. 21:1392-1409.

Dong, W., W.P. Ball, C. Liu, Z. Wang, A.T. Stone, J. Bai, and J.M. Zachara. 2005. Influence of calcite and dissolved calcium on uranium(VI) sorption to a Hanford subsurface sediment. Environ. Sci. Technol. 39:7949-7955.

Dresel, P.E., J.C. Evans, and O.T. Farmer, III. 2002. Investigation of isotopic signatures for sources of groundwater contamination at the Hanford Site. PNNL-13763. Pacific Northwest National Laboratory, Richland, WA.

Eary, L.E., and D. Rai. 1987. Kinetics of chromium(III) oxidation to chromium(VI) by reaction with manganese-dioxide. Environ. Sci. Technol. 21(12):1187-1193.

Elzinga, E.J., C.D. Tait, R.J. Reeder, K.D. Rector, R.J. Donohoe, and D.E. Morris. 2004. Spectroscopic investigation of U(VI) sorption at the calcite- 
water interface. Geochim. Cosmochim. Acta 68(11):2437-2448.

Evans, J.C., P.E. Dresel, and O.T. Farmer, III. 2007. Inductively coupled plasma/ mass spectrometric isotopic determination of nuclear wastes sources associated with Hanford tank leaks. Vadose Zone J. 6:1042-1049 (this issue).

Flury, M., J.B. Mathison, and J.B. Harsh. 2002. In situ mobilization of colloids and transport of cesium in Hanford sediments. Environ. Sci. Technol. 36:5335-5341

Fox, P.M., J.A. Davis, and J.M. Zachara. 2006. The effect of calcium on aqueous uranium(VI) speciation and adsorption to ferrihydrite and quartz. Geochim. Cosmochim. Acta 70(6):1379-1387.

Fredrickson, J.K., F.J. Brockman, B.N. Bjornstad, P.E. Long, S.-M. Li, J.P. McKinley, J.V. Wright, J.L. Conca, T.L. Kieft, and D.L. Balkwill. 1993. Microbiological characteristics of pristine and contaminated deep vadose sediments from an arid region. Geomicrobiol. J. 11:95-107.

Fredrickson, J.K., and T.C. Onstott. 2001. Biogeochemical and geological significance of subsurface microbiology. p. 3-37. In J.K. Fredrickson and M. Fletcher (ed.) Subsurface microbiology and biogeochemistry. WileyLISS, New York.

Fredrickson, J.K., J.M. Zachara, D.L. Balkwill, D. Kennedy, S.-M. Li, H.M. Kostandarithes, M.J. Daly, M.F. Romine, and F.J. Brockman. 2004. Geomicrobiology of high-level nuclear waste-contaminated vadose sediments at the Hanford Site, Washington State. Appl. Environ. Microbiol. 70(7):4230-4241.

Freeman-Pollard, J.R., J.A. Caggiano, S.J. Trent, and H. Crowser. 1994. Engineering evaluation of the GAO/RCED-89-157, tank 241-T-106 vadose zone investigations. BHI-00061, Rev. 00. Bechtel Hanford, Richland, WA.

Freeze, R.A., and J.A. Cherry. 1979. Groundwater. Prentice Hall, Englewood Cliffs, NJ.

Gabriel, U., J.-P. Gaudet, L. Spadini, and L. Charlet. 1998. Reactive transport of uranyl in a goethite column: An experimental and modeling study. Chem. Geol. 151:107-128.

Gephart, R.E., and R.E. Lundgren. 1996. Hanford tank clean up: A guide to understanding the technical issues. PNL-10773. Pacific Northwest National Laboratory, Richland, WA.

Ginder-Vogel, M., T. Borch, M.A. Mayes, P.M. Jardine, and S. Fendorf. 2005. Chromate reduction and retention processes within arid subsurface environments. Environ. Sci. Technol. 39:7833-7839.

Goldberg, S., H.S. Forster, and C.L. Godfrey. 1996. Molybdenum adsorption on oxides, clay minerals, and soils. Soil Sci. Soc. Am. J. 60(2):425-432.

Goldberg, S., S.M. Lesch, and D.L. Suarez. 2002. Predicting molybdenum adsorption by soils using soil chemical parameters in the constant capacitance model. Soil Sci. Soc. Am. J. 66(6):1836-1842.

Hanlon, B.M. 1995. Waste tank summary for month ending June 30, 1995. WHC-EP-0182-87. Westinghouse Hanford Company, Richland, WA.

Hartman, M.J. 2000. Hanford Site groundwater monitoring: Setting, sources, and methods. Pacific Northwest National Laboratory, Richland, WA.

Hartman, M.J., L.F. Morasch, and W.D. Webber. 2005. Hanford Site groundwater monitoring for fiscal year 2004. PNNL-15070. Pacific Northwest National Laboratory, Richland, WA.

Hayes, K.F., C. Papelis, and J.O. Leckie. 1988. Modeling ionic strength effects on anion adsorption and hydrous oxide/solution interfaces. J. Colloid Interface Sci. 78:717-726.

He, Y.T., J.M. Bigham, and S.J. Traina. 2005. Biotite dissolution and Cr(VI) reduction at elevated $\mathrm{pH}$ and ionic strength. Geochim. Cosmochim. Acta 69(15):3791-3800.

Honeyman, B.D. 1999. Colloidal culprits in contamination. Nature 397:23.

Jones, T.E., B.C. Simpson, M.I. Wood, and R.A. Corbin. 2000a. Preliminary inventory estimates for single-shell tank leaks in T, TX, and TY tank farms. RPP-7218. CH2M HILL Hanford Group, Richland, WA.

Jones, T.E., R.A. Watrous, and G.T. Maclean. 2000b. Inventory estimates for single-shell tank leaks in S and SX tank farms. RPP-6285, Rev. 0. CH2M HILL Hanford Group, Richland, WA.

Jones, T.E., M.I. Wood, R.A. Corbin, and B.C. Simpson. 2001. Preliminary inventory estimates for single-shell tank leaks in B, BX, and BY tank farms. RPP-7389. CH2M HILL Hanford Group, Richland, WA.

Kaplan, D.I., and R.J. Serne. 1998. Pertechnetate exclusion from sediments. Radiochim. Acta 81(2):117-124.

Kelly, S.D., M.G. Newville, L. Cheng, K.M. Kemner, S.R. Sutton, P. Fenter,
N.C. Sturchio, and C. Spotl. 2003. Uranyl incorporation in natural calcite. Environ. Sci. Technol. 37:1284-1287.

Kersting, A.B., D.W. Efurd, D.L. Finnegan, D.J. Rokop, D.K. Smith, and J.L. Thompson. 1999. Migration of plutonium in ground water at the Nevada test site. Nature 397(6714):56-59.

Khaleel, R., M.D. White, M. Oostrom, M.I. Wood, F.M. Mann, and J.G. Kristofzski. 2007. Impact assessment of existing vadose zone contamination at the Hanford Site SX tank farm. Vadose Zone J. 6:935-945 this issue.

Kieft, T.L., P.S. Amy, F.J. Brockman, J.K. Fredrickson, B.N. Bjornstad, and L.L. Rosacker. 1993. Microbial abundance and activities in relation to water potential in the vadose zones of arid and semiarid sites. Microbiol. Ecol. 26:59-78.

Knepp, A.J. 2002a. Field investigation report for waste management area S-SX RPP-7884. CH2M HILL Hanford Group, Richland, WA.

Knepp, A.J. 2002b. Field investigation report for waste management Area B-BXBY RPP-10098. CH2M HILL Hanford Group, Richland, WA.

Kohler, M., G.P. Curtis, D.B. Kent, and J.A. Davis. 1996. Experimental investigation and modeling of uranium(VI) transport under variable chemical conditions. Water Resour. Res. 32(12):3539-3551.

Konhauser, K. 2007. Introduction to geomicrobiology. Blackwell, Malden, MA.

Lichtner, P.C., S. Yabusaki, K. Pruess, and C.I. Steefel. 2004. Role of competitive cation exchange on chromatographic displacement of cesium in the vadose zone beneath the Hanford S/SX tank farm. Vadose Zone J. 3:203-219.

Lindsey, K.A. 1995. Miocene- to Pliocene-aged suprabasalt sediments of the Hanford Site, south-central Washington. BHI-00184. Bechtel Hanford, Richland, WA.

Lindsey, K.A. 1996. Miocene-Pliocene Ringold Formation and associated deposits of the ancestral Columbia River system, south-central Washington and north-central Oregon. Washington Open-File Report 96-8. Department of Natural Resources, Division of Geology and Earth Resources, Olympia, WA.

Liu, C., J.M. Zachara, and S.C. Smith. 2004. A cation exchange model to describe $\mathrm{Cs}^{+}$sorption at high ionic strength in subsurface sediments from the Hanford Site, USA. J. Contam. Hydrol. 68:217-238.

Liu, C., J.M. Zachara, S.C. Smith, J.P. McKinley, and C.C. Ainsworth. 2003. Desorption kinetics of radiocesium from subsurface sediments at the Hanford Site, USA. Geochim. Cosmochim. Acta 67(16):2893-2912.

Liu, Y., T.M. Louie, J. Payne, J. Bohuslavek, H. Bolton, Jr., and L.Y. Xun. 2001. Identification, purification, and characterization of iminodiacetate oxidase from the EDTA-degrading bacterium BNC1. Appl. Environ. Microbiol. 67(2):696-701.

Lukens, W.W., J.J. Bucher, N.M. Edelstein, and D.K. Shuh. 2001. Radiolysis of $\mathrm{TcO}_{4}{ }^{-}$in alkaline, nitrate solutions: Reduction by $\mathrm{NO}_{3}{ }^{2-}$. J. Phys. Chem. A 105:9611-9615.

Lukens, W.W., J.J. Bucher, N.M. Edelstein, and D.K. Shuh. 2002. Products of pertechnetate radiolysis in highly alkaline solution: Structure of $\mathrm{TcO}_{2} \cdot \mathrm{nH}_{2} \mathrm{O}$. Environ. Sci. Technol. 36(5):1124-1129.

Marshal, K., J.B. Harsh, M. Flury, A.R. Felmy, and H. Zhao. 2004. Colloid formation in Hanford sediments reacted with simulated tank waste. Environ. Sci. Technol. 38:5750-5756.

McCarthy, J.F., and J.M. Zachara. 1989. Subsurface transport of contaminants. Environ. Sci. Technol. 23(5):496-502.

McKinley, J.P., J.M. Zachara, S.C. Smith, and C. Liu. 2007. Cation exchange reactions controlling desorption of ${ }^{90} \mathrm{Sr}^{2+}$ from coarse-grained contaminated sediments from the Hanford formation, Washington. Geochim. Cosmochim. Acta 71(2):305-324.

McKinley, J.P., C.J. Zeissler, J.M. Zachara, R.J. Serne, R.M. Lindstrom, and H.T. Schaef. 2001. Distribution and retention of ${ }^{137} \mathrm{Cs}$ in sediments at the Hanford Site, Washington. Environ. Sci. Technol. 35:3433-3441.

Means, J.L., and C.A. Alexander. 1981. Environmental biogeochemistry of chelating agents and recommendations for the disposal of chelated radioactive wastes. Nucl. Chem. Waste Manage. 2:183-196.

Means, J.L., D.A. Crerar, and J.O. Duguid. 1978. Migration of radioactive wastes: Radionuclide mobilization by complexing agents. Science 200:1477-1481.

Mon, J., Y. Deng, M. Flury, and J.B. Harsh. 2005. Cesium incorporation and diffusion in cancrinite, sodalite, zeolite, and allophone. Microporous Mesoporous Mater. 86:277-286.

Myers, D.A. 2005. Field investigation report for waste management area T-TX- 
TY. RPP-23752. CH2M HILL Hanford Group, Richland, WA.

Olsen, C.R., P.D. Lowry, S.Y. Lee, I.L. Larsen, and N.H. Cutshall. 1986. Geochemical and environmental processes affecting radionuclide migration from a formerly used seepage trench. Geochim. Cosmochim. Acta 50:593-607.

Pabalan, R.T., and D.R. Turner. 1997. Uranium(VI) sorption on montmorillonite: Experimental and surface complexation modeling study. Aquat. Geochem. 2:203-226

Pabalan, R.T., D.R. Turner, F.P. Bertetti, and J.D. Prikryl. 1998. Uranium(VI) sorption onto selected mineral surfaces: Key geochemical parameters. p. 99-130. In E.A. Jenne (ed.) Adsorption of metals by geomedia: Variables, mechanisms, and model applications. Academic Press, San Diego, CA.

Pace, M.N., M.A. Mayes, P.M. Jardine, T.L. Mehlhorn, J.M. Zachara, and B.N. Bjornstad. 2004. Quantifying the effects of small-scale heterogeneities on flow and transport in undisturbed cores from the Hanford formation. Vadose Zone J. 2:664-676.

Prikryl, J.D., A. Jain, D.R. Turner, and R.T. Pabalan. 2001. Uranium(VI) sorption behavior of silicate mineral mixtures. J. Contam. Hydrol. 47:241-253.

Pruess, K., S. Yabusaki, C.I. Steefel, and P.C. Lichtner. 2002. Fluid flow, heat transfer, and solute transport at nuclear waste storage tanks in the Hanford vadose zone. Vadose Zone J. 1:68-88.

Qafoku, N.P., C.C. Ainsworth, J.E. Szecsody, and O.S. Qafoku. 2003. Effect of coupled dissolution and redox reactions on $\mathrm{Cr}(\mathrm{VI})_{\mathrm{aq}}$ attenuation during transport in the sediments under hyperalkaline conditions. Environ. Sci. Technol. 37:3640-3646.

Qafoku, N.P., C.C. Ainsworth, J.E. Szecsody, and O.S. Qafoku. 2004. Transportcontrolled kinetics of dissolution and precipitation in the sediments under alkaline and saline conditions. Geochim. Cosmochim. Acta 68(14):29812995.

Qafoku, N.P., J.M. Zachara, C. Liu, P.L. Gassman, O.S. Qafoku, and S.C. Smith. 2005. Kinetic desorption and sorption of $\mathrm{U}(\mathrm{VI})$ during reactive transport in a contaminated Hanford sediment. Environ. Sci. Technol. 39:3157-3165.

Raats, P.A.C., Z.F. Zhang, A.L. Ward, and G.W. Gee. 2004. The relative connectivity-tortuosity tensor for conduction of water in anisotrophic unsaturated soils. Vadose Zone J. 3:1471-1478.

Rai, D., H. Bolton, Jr., D.A. Moore, N.J. Hess, and G.R. Choppin. 2001. Thermodynamic model for the solubility of $\mathrm{PuO}_{2}(\mathrm{am})$ in the aqueous $\mathrm{Na}^{+}-\mathrm{H}^{+}-\mathrm{OH}-\mathrm{Cl}-\mathrm{H}_{2} \mathrm{O}$-ethylenediaminetetraacetate system. Radiochim. Acta 89(2):67-74.

Remund, K.M., C.M. Anderson, and B.C. Simpson. 1995. Hanford single-shell tank grouping study. Westinghouse Hanford Company, Richland, WA.

Roy, S.B., and D.A. Dzombak. 1997. Chemical factors influencing colloidfacilitated transport of contaminants in porous media. Environ. Sci. Technol. 31:656-664.

Samson, S.D., K.L. Nagy, and W.B. Cotton, III. 2005. Transient and quasisteady-state dissolution of biotite at $2225^{\circ} \mathrm{C}$ in high $\mathrm{pH}$, sodium, nitrate, and aluminate solutions. Geochim. Cosmochim. Acta 69(2):399-413.

Savenko, A.V. 2001. Sorption of $\mathrm{UO}_{2}{ }^{2+}$ on calcium carbonate. Radiochemistry 43:193-196.

Sen, T.K., and K.C. Khilar. 2006. Review on subsurface colloids and colloidassociated contaminant transport in saturated porous media. Adv. Colloid Interface Sci. 119:71-96.

Serne, R.J., B.N. Bjornstad, G.W. Gee, H.T. Schaef, D.C. Lanigan, R.G. McCain, C.W. Lindenmeier, R.D. Orr, V.L. LeGore, R.E. Clayton, J.W. Lindberg, I.V. Kutnyakov, S.R. Baum, K.N. Geiszler, M.M. Valenta, T.S. Vickerman, and L.J. Royack. 2002a. Characterization of vadose zone sediment: Borehole 299-E33-46 near B-110 in the B-BX-By waste management area. PNNL-14119. Pacific Northwest National Laboratory, Richland, WA.

Serne, R.J., B.N. Bjornstad, D.G. Horton, D.C. Lanigan, C.W. Lindenmeier, M.J. Lindberg, R.E. Clayton, V.L. LeGore, R.D. Orr, I.V. Kutnyakov, S.R. Baum, K.N. Geiszler, M.M. Valenta, and T.S. Vickerman. 2004a. Characterization of vadose zone sediments below the TX tank farm: Boreholes C3830, C3831, C3832, and RCRA borehole 299-W10-27. PNNL-14594. Pacific Northwest National Laboratory, Richland, WA.

Serne, R.J., B.N. Bjornstad, D.G. Horton, D.C. Lanigan, H.T. Schaef, C.W. Lindenmeier, J.W. Lindberg, R.E. Clayton, V.L. LeGore, K.N. Geiszler, S.R. Baum, M.M. Valenta, I.V. Kutnyakov, T.S. Vickerman, R.D. Orr, and C.F. Brown. 2004b. Characterization of vadose zone sediments below the T tank farm: Boreholes C4104, C4105, 299-W10-196, and RCRA Borehole 299-W11-39. PNNL-14849. Pacific Northwest National Laboratory, Richland, WA.

Serne, R.J., G.V. Last, G.W. Gee, H.T. Schaef, D.C. Lanigan, C.W. Lindenmeier, J.W. Lindberg, R.E. Clayton, V.L. LeGore, R.D. Orr, I.V. Kutnyakov, S.R. Baum, K.N. Geiszler, C.F. Brown, M.M. Valenta, and T.S. Vickerman. 2002b. Characterization of vadose zone sediment: Borehole 299-E33-45 near BX-102 in the B-BX-BY waste management. PNNL-14083. Pacific Northwest National Laboratory, Richland, WA.

Serne, R.J., G.V. Last, H.T. Schaef, D.C. Lanigan, C.W. Lindenmeier, C.C. Ainsworth, R.E. Clayton, and V.L. LeGore. M.J. O-Hara, C.F. Brown, R.D. Orr, I.V. Kutnyakov, T.C. Wilson, K.B. Wagnon, B.A. Williams, and D.S. Burke. 2002c. Characterization of vadose zone sediment: Borehole 41-09-39 in the S-SX waste management area. PNNL-13757-3. Pacific Northwest National Laboratory, Richland, WA.

Serne, R.J., G.V. Last, H.T. Schaef, D.C. Lanigan, C.W. Lindenmeier, C.C. Ainsworth, R.E. Clayton, V.L. LeGore, M.J. O-Hara, C.F. Brown, R.D. Orr, I.V. Kutnyakov, T.C. Wilson, K.B. Wagnon, B.A. Williams, and D.S. Burke. 2002d. Characterization of vadose zone sediment: Slant borehole SX-108 in the S-SX waste management. PNNL-13757-4, CH2M HILL Hanford Group, Richland, WA.

Serne, R.J., H.T. Schaef, B.N. Bjornstad, D.C. Lanigan, G.W. Gee, C.W. Lindenmeier, R.E. Clayton, V.L. LeGore, and R.D. Orr. M.J. O-Hara, C.F. Brown, G.V. Last, I.V. Kutnyakov, D.S. Burke, T.C. Wilson, and B.A. Williams. 2002e. Characterization of vadose zone sediment: Borehole 299W23-19 [SX-115] in the S-SX waste management area. PNNL-13757-2. Pacific Northwest National Laboratory, Richland, WA.

Simpson, B.C., R.A. Corbin, C.M. Anderson, C.T. Kincaid, and J.M. Zachara. 2006. Identification and classification of the major uranium discharges and unplanned releases at the Hanford Site using the Soil Inventory Model (SIM), Rev. 1 results. NUV-06-21106-ES-001-DOC Rev. 1. Nuvotec USA, Richland, WA.

Sposito, G. 1981. The thermodynamics of soil solutions. Oxford Univ. Press, Oxford, UK

Sposito, G. 1984. The surface chemistry of soils. Oxford Univ. Press, New York.

Steefel, C.I., S.A. Carroll, P. Zhao, and S. Roberts. 2003. Cesium migration in Hanford sediment: A multi-site cation exchange model based on laboratory transport experiments. J. Contam. Hydrol. 67:219-246.

Steefel, C.I., D.J. DePaolo, and P.C. Lichtner. 2005. Reactive transport modeling: An essential tool and a new research approach for the Earth sciences. Earth Planetary Sci. Lett. 240:539-558.

Stumm, W. 1992. Chemistry of the solid-water interface: Processes at the mineral-water and particle-water interface in natural systems. John Wiley $\&$ Sons, New York.

Tallman, A.M., K.R. Fecht, M.C. Marratt, and G.V. Last. 1979. Geology of the separations areas, Hanford Site, south-central Washington. RHO-ST-23. Rockwell Hanford Operations, Richland, WA.

Thornton, E.C., and J.W. Lindberg. 2002. Data quality objectives summary report: Designing a groundwater monitoring network for the 200-BP-5 and 200-PO-1 operable units. Pacific Northwest National Laboratory, Richland, WA.

Toste, A.P. 1991. Analyzing exotic organics in mixed nuclear wastes: The challenges. Abstr. Papers Am. Chem. Soc. 202:60.

Toste, A.P., and T.J. Lechner-Fish. 1993. Chemo-degradation of chelating and complexing agents in a simulated, mixed nuclear waste. Waste Manage. $13: 237-244$

Toste, A.P., K.J. Polach, and T.W. White. 1994. Degradation of citric acid in a simulated, mixed nuclear waste: Radiolytic versus chemical forces. Waste Manage. 14(1):27-34.

Um, W., and R.J. Serne. 2005. Sorption and transport behavior of radionuclides in the proposed low-level radioactive waste disposal facility at the Hanford site, Washington. Radiochim. Acta 93(1):57-63.

Um, W., R.J. Serne, and K.M. Krupka. 2007. Surface complexation modeling of $\mathrm{U}(\mathrm{VI})$ sorption to Hanford sediment with varying geochemical conditions. Environ. Sci. Technol. 41(10):3587-3592.

Um, W., R.J. Serne, S.B. Yabusaki, and A.T. Owen. 2005. Enhanced radionuclide immobilization and flow path modifications by dissolution and secondary precipitates. J. Environ. Qual. 34(4):1404-1414.

USDOE. 1988. Consultation draft site characterization plan, reference repository 
location, Hanford Site, Washington. DOE/RW-0164. USDOE, Office of Civilian Radioactive Waste Management, Washington, DC.

USDOE. 2002. Standardized stratigraphic nomenclature for post-RingoldFormation sediments within the Pasco Basin. DOE/RL-2002-39. USDOE, Richland Operations Office, Richland, WA.

USDOE. 2006. Initial single-shell tank system performance assessment for the Hanford Site. DOE/ORP-2005-01, Rev. 0. USDOE, Office of River Protection, Richland, WA.

VanBriesen, J.M., B.E. Rittmann, L. Xun, D.C. Girvin, and H. Bolton, Jr. 2000. The rate-controlling substrate of nitrilotriacetate for biodegradation by Chelatobacter heintzii. Environ. Sci. Technol. 34(16):3346-3353.

Waite, T.D., J.A. Davis, T.E. Payne, G.A. Waychunas, and N. Xu. 1994. Uranium(VI) adsorption to ferrihydrite: Application of a surface complexation model. Geochim. Cosmochim. Acta 58:5465-5478.

Wan, J., J.T. Larsen, T.K. Tokunaga, and Z. Zheng. 2004a. pH neutralization and zonation in alkaline-saline tank waste plumes. Environ. Sci. Technol. 38:1321-1329.

Wan, J., T.K. Tokunaga, J.T. Larsen, and R.J. Serne. 2004b. Geochemical evolution of highly alkaline and saline tank waste plumes during seepage through vadose zone sediments. Geochim. Cosmochim. Acta 68(3):491502.

Wan, J., T.K. Tokunaga, E. Saiz, J.T. Larsen, and R.A. Couture. 2004c. Colloid formation at waste plume fronts. Environ. Sci. Technol. 38:6066-6073.

Wang, Z., J.M. Zachara, J.P. McKinley, S.C. Smith, and S.M. Heald. 2005. Cryogenic laser induced U(VI) fluorescence studies of a U(VI) substituted natural calcite: Implications to U(VI) speciation in contaminated Hanford sediments. Environ. Sci. Technol. 39:2651-2659.

Ward, A.L., M.E. Conrad, W.D. Daily, J.B. Fink, V.L. Freedman, G.W. Gee, G.M. Hoverston, M.J. Keller, E.L. Majer, C.J. Murray, M.D. White, S.B. Yabusaki, and Z.F. Zhang. 2006a. Vadose zone transport field study summary report. PNNL-15443. Pacific Northwest National Laboratory, Richland, WA.

Ward, A.L., and Z.F. Zhang. 2007. Effective hydraulic properties determined from transient unsaturated flow in anisotropic soils. Vadose Zone J. 6:913924 (this issue).

Ward, A.L., Z.F. Zhang, and G.W. Gee. 2006b. Upscaling unsaturated hydraulic parameters for flow through heterogeneous anisotropic sediments. Adv. Water Resour. 29(2):268-280.

Wazne, M., G.P. Korfiatis, and X. Meng. 2003. Carbonate effects on hexavalent uranium adsorption by iron oxyhydroxide. Environ. Sci. Technol. 37:3619-3624.

Wu, L., W. Forsling, and P.W. Schindler. 1991. Surface complexation of calcium minerals in aqueous solution: 1 . Surface protonation at fluorapatite-water interfaces. J. Colloid Interface Sci. 147(1):178-185.

Yeh, G.T., and V.S. Tripathi. 1989. A critical evaluation of recent developments in hydrogeochemical transport models of reactive multichemical components. Water Resour. Res. 25:93-108.

Zachara, J.M., C.C. Ainsworth, C.E. Cowan, and C.T. Resch. 1989. Adsorption of chromate by subsurface soil horizons. Soil Sci. Soc. Am. J. 53:364373.

Zachara, J.M., G.E. Brown, Jr., C.C. Ainsworth, S.J. Traina, J.P. McKinley, J. Catalano, O.S. Qafoku, J.E. Szecsody, and S.C. Smith. 2004. Chromium speciation and mobility in a high level nuclear waste plume. Geochim. Cosmochim. Acta 68(1):13-30.

Zachara, J.M., C.E. Cowan, and C.T. Resch. 1991. Sorption of divalent metal ions on calcite: Application of a surface exchange model. Geochim. Cosmochim. Acta 55:1549-1562.

Zachara, J.M., P.L. Gassman, S.C. Smith, and D. Taylor. 1995. Oxidation and adsorption of $\mathrm{Co}(\mathrm{II}) \mathrm{EDTA}^{2-}$ complexes in subsurface materials with iron and manganese oxide grain coatings. Geochim. Cosmochim. Acta 59:4449-4463.

Zachara, J.M., D.C. Girvin, R.L. Schmidt, and C.T. Resch. 1987. Chromate adsorption on amorphous iron oxyhydroxide in presence of groundwater major ions. Environ. Sci. Technol. 21:589-594.

Zachara, J.M., S.M. Heald, B.H. Jeon, R.K. Kukkadapu, C. Liu, J.P. McKinley, A.C. Dohnalkova, and D.A. Moore. 2007. Reduction of pertechnetate $[\mathrm{Tc}(\mathrm{VII})]$ by aqueous $\mathrm{Fe}(\mathrm{II})$ and the nature of solid phase redox products. Geochim. Cosmochim. Acta 71:2137-2157.

Zachara, J.M., S.C. Smith, C. Liu, J.P. McKinley, R.J. Serne, and P.L. Gassman. 2002. Sorption of $\mathrm{Cs}^{+}$to micaceous subsurface sediments from the
Hanford Site, USA. Geochim. Cosmochim. Acta 66(2):193-211.

Zeissler, C.J., R.M. Lindstrom, and J.P. McKinley. 2001. Radioactive particle analysis by digital autoradiography. J. Radioanal. Nucl. Chem. 248(2):407412.

Zhang, G., Z. Zheng, and J. Wan. 2005. Modeling reactive geochemical transport of concentrated aqueous solutions. Water Resour. Res. 41: W02018, doi:10.1029/2004WR003097.

Zhang, Z.F., A.L. Ward, and G.W. Gee. 2003. Describing the unsaturated hydraulic properties of anisotropic soils using a tensorial connectivitytortuosity (TCT) concept. Vadose Zone J. 2:313-321.

Zhu, C. 2003. A case against Kd based transport models: Natural attenuation at a mill tailings site. Comput. Geosci. 29:351-359.

Zhuang, J., M. Flury, and Y. Jin. 2003. Colloid-facilitated Cs transport through water-saturated Hanford sediment and Ottawa sand. Environ. Sci. Technol. 37:4905-4911.

Zhuang, J., Y. Jin, and M. Flury. 2004. Comparison of Hanford colloids and kaolinite transport in porous media. Vadose Zone J. 3:395-402. 